\title{
An overview of global energy scenarios by 2040 : identifying the driving forces using cross-impact analysis method
}

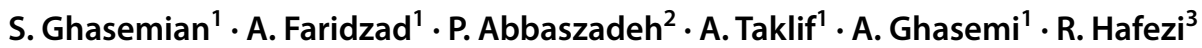

Received: 27 November 2019 / Revised: 11 March 2020 / Accepted: 6 April 2020

(c) The Author(s) 2020

\begin{abstract}
This study presents a novel comparative analysis on global energy scenarios in terms of main characteristics, scenario building frameworks and time frames. The study analyzes each energy scenario's outputs and outlooks by 2040 such as gross domestic product growth, technology developments, primary energy demand by sector, energy supply by fuel, energy intensity and carbon emissions. Based on the foresight semiquantitative method, global energy driving forces which play significant roles in reshaping the world energy future by 2040 have been identified. The study applies mathematical principles to quantify the rational judgments of an expert panel in social, technological, economic, environmental and political framework through cross-impact analysis. Among the 10 global energy driving forces by 2040, population growth rate and climate change are identified as social and environmental driving forces, respectively. Investment in infrastructures, financial shocks, consumer behavior and energy efficiency are marked as economic driving forces, while global governance and geopolitical relationships are identified as the global energy market's political driving force. And finally, technological development in renewable energies as well as in oil and gas upstream sector is recognized as a technological driving force.
\end{abstract}

Keywords Energy markets $\cdot$ Foresight $\cdot$ Global trends $\cdot$ Scenario analysis

\section{Introduction}

For decades, long-term changes in the production and consumption of energy resources have been the focus of attention of energy economists (Cherp et al. 2018). Since the 1970s, the uncertainties existing in energy markets, especially in oil markets, have been of prime practical significance (Yergin 2011).

This paper aims to advance this debate by reviewing world energy scenarios and analyzing the driving forces in

Editorial responsibility: M. Abbaspour.

A. Taklif

a.taklif@atu.ac.ir

1 Department of Energy, Agriculture and Environmental Economics, Faculty of Economics, Allameh Tabataba'i University, Tehran, Iran

2 Technology Foresight, Department of Management, Science and Technology, Amirkabir University of Technology (Tehran Polytechnic), Tehran, Iran

3 Futures Studies Research Group, National Research Institute for Science Policy (NRISP), Tehran, Iran the global energy market. The future of energy supply and demand are subject to large uncertainties, and it is difficult to predict the trends of influencing factors such as energy prices, world economic growth rates, demographic changes, technological advances, government policies, and consumer behavior (Jefferson 2000; Pearson 2016).

Over the past four decades, the world's rapid growth in energy demand has mainly been satisfied by fossil fuels. Oil, coal, natural gas, hydroelectric, nuclear energy, and renewables accounted for 33.6, 27.2, 23.9, 6.8, 4.4 and $4 \%$ of the world's primary energy consumption in 2018 , respectively. On the other hand, fossil fuels accounted for $84.7 \%$ of world primary energy consumption in 2018 (BP 2019).

The global social, economic, political, environmental and technological changes create a fundamentally different outlook for the international energy markets. It is expected that a different future would be characterized by shale oil and shale gas revolution (Zahid et al. 2007; Alhajji et al. 2018) and growth of other unconventional resources, rapid technological development, lower population growth, the rise of renewables share in the world primary energy basket, widespread decarbonization plans, urbanization growth, changing 
economic and political power blocs, climate change and its associated environmental concerns (BP 2017).

Population growth, population ageing, migration and urbanization are the demographic megatrends in 2040 and social key factors of global energy system (UN 2019). The impressive growth in the Middle East and Africa is predicted to become the world's most populated regions in the world by 2030 . The demographic trends also show that the population growth will be $0.7 \%$ by 2040 which unprecedentedly decreased compared to the last few decades (EIA 2016).

Economic growth is one of the main key drivers behind energy demand. Higher economic growth is generally associated with higher energy demand, hence the need for more supply (Bhattacharyya 2011). Moreover, energy plays an important role in the long-run economic growth. By comparison with capital and labor, energy signifies more importance as a factor of production, albeit having a small cost-share (Ayres et al. 2013). However, long-term economic growth is driven mainly by technological development, demographic trends, environmental and governmental policies and energy market development (Stern 2010).

Global GDP between 2015 and 2030 is expected to increase at an average rate of $3.55 \%$ per annum or about $75 \%$ total increase as compared to 2015 (BP 2017). This growth is predicted to be mainly driven by labor productivity and efficiency.

In this period, energy systems and markets are expected to be highly influenced by government policies, international cooperation on environmental, technological and economic issues.

The energy industry is highly dependent on technology development. Hence, technological change will be of critical importance for the future energy systems (Nakicenovic et al. 1998).

Technology development in the field of renewables has led to a significant increase in its share of the entire primary energy portfolio of the world. Renewable energies are conducive in reducing greenhouse gas emissions over the coming decades. The share of renewable energies in the total primary energy consumption of the world is increasing from $9.5 \%$ in 2015 to $63 \%$ in 2050 (Gielen et al. 2019).

In this study, we aim to analyze the major global energy scenarios in terms of their main characteristics, scenario building frameworks, time frames and results.

The global energy scenarios reviewed in this study are selected based on crucial considerations such as international validity, variety of scenario building frameworks and diversity of authorship, including international petroleum corporations, global policy agencies, international NGOs and global policy networks. All of these scenarios are global studies with no specific regional focus, and in the term of time horizon, investigate 2030 and later. These scenarios have been published in 2011 and after and aimed to represent the whole energy system.

The selected scenarios contain a wide range of input assumptions, e.g. optimistic or pessimistic approach to the future share of renewable energies and the key factors with respect to social, technological, economic, environmental and political (STEEP) framework.

In the literature review, many studies that mentioned the areas of uncertainty in the global energy system have been reviewed. This section reviews on global energy drivers in social, environmental, economic, political and technological approaches.

The Materials and methods section deals with selected global energy scenarios in a novel approach. The characteristics, frameworks, time horizon and the models used in each scenario are briefly discussed. This section presents a comparative analysis of selected global energy scenarios and outlines the International Energy Agency (IEA), British Petroleum (BP), World Energy Council (WEC), Greenpeace (GP), ExxonMobil, and Shell projections for the future of global energy market. This section also analyzes the future trend of energy demand by sector, global energy supply of different fuels, energy intensity and carbon emissions.

The Methodology section examines 40 key factors of global energy scenarios by Delphi method based on the academic literature review of global energy systems and reviewed world energy scenarios. According to foresight semiquantitative method, the driving forces of international energy markets in 2040 are identified by the cross-impact analysis (CIA), which is one of the most commonly used techniques for future studies and scenario planning.

Results and discussion reviews the major findings of this paper, followed by the Conclusion of this study in the final section. The present research work has been carried out at the Department of Energy, Agriculture and Environmental Economics, Allameh Tabataba'i University in Tehran in 2018-2019.

\section{Literature review}

The dominant view in the academic literature is that the global energy market has changed rapidly in recent years (Benedict 2017; Gilbert and Sovacool 2016).

Grübler et al. (1996) and Nakicenovic et al. (1998) have identified several key drivers for the future of world energy market including population growth, economic growth, improved energy intensity, technological change, access to conventional and unconventional oil and gas resources, and environmental considerations of carbon emission levels.

Cherp et al. (2018) suggests a system approach to global energy analysis in which a mixture of different methods is used. More recently, global energy scenarios have focused 
on social considerations in addition to technological and economic dimensions (Ernst et al. 2018).

Dahl (2015) reviewed energy drivers in terms of social and economic approach. She has mentioned that the world economic and income growth of different countries are the main economic drivers and the population growth rate and life expectancy are considered to be the most important social factors playing significant roles in reshaping the future global energy system.

Ansari and Holz (2019) identified four major drivers including population growth and urbanization, energy cost reduction, fossil fuel availability, and economic integration using the STEMPLE framework.

Technological progress as one of the major global trends has led to the fossil energy dominance in the global energy market up to 2040 (Grubler et al. 1995; Blazev 2016).

According to Florini and Sovacool (2009), the inappropriate governance, government intervention in the pricing system, and lack of investment are important factors adversely influencing the future of international energy markets. Wang and $\mathrm{Li}$ (2016) maintained that the technological advancement, population growth and gross domestic product growth will be the main energy drivers in China and India.

Huang (2014) has considered structural, demographic, technological and temperature changes as the main drivers of the global energy demand. Gielen et al. (2019) introduced the energy efficiency and renewable energy technologies as the major drivers of energy transition to 2050 .

Energy scenarios produced by influential global organizations such as Shell, WEC and IEA matter because they may affect what would actually take place. These organizations may shape the expectations of decision-makers in related energy sectors (Alipour et al. 2018; Carrington and Stephenson 2018; Hafezi et al. 2017).

In the 1970s, Shell's successful prediction of the events in world oil market, like the oil shock, drew the attention of experts and professionals to the importance of energy foresight studies (Jefferson 2012; Hafezi 2019). Several studies reviewed Shell's experience in scenario analysis and presented different narrative to what was found in the existing literature.

These studies highlighted the importance of exploring the emerging trends and key factors of global energy markets in Shell's scenarios and concluded that the Shell scenarios go beyond the conventional energy outlooks and consider long-term trends in economics, energy supply and demand, geopolitical shifts and social changes (Zalik 2010; Jefferson 2012; Bentham 2014).

Several studies reviewed the methodology behind IEA's World Energy Outlook (Mohn 2016; Junne et al. 2019). Mohn (2016) has criticized the outlook projected by IEA for economic growth, technological change, and investment in new renewable energy.

Junne et al. (2019) proposed some technical points in terms of transparency and traceability after reviewing three energy scenarios including the IEA report.

\section{Materials and methods}

Scenario is a description of future situations and one of the most basic concepts of future studies (Schoemaker 1991; Hafezi et al. 2019). It has been introduced as an effective tool for companies and firms to get ready for possible futures. Scenario analyzing is an analytic technique for analyzing trends over the target field, but also it is output of analyses (Fontela and Hingel 1993).

Scenario building is important for many reasons, including analyzing possible future images and clarifying strategic options for decision makers (Mietzner and Reger 2005).

Scenarios provide the description of future situation and the development or portrayal of the path that leads us out of today and into the future (Godet 2000, 2006; Jungk and Müllert 1996; Gordon and Glenn 2018).

Each global energy scenario reflects a summarized and abstract version of a possible future predicted by relations between the enormous amount of data and descriptive clauses in different fields of energy. Relations between parameters of energy scenarios are usually defined by the combination of policy shifts, trends in international policies, economic development, and technological innovations (Bhattacharyya and Timilsina 2010; Cao et al. 2016).

Energy scenarios differ from each other due to the diversity of drivers, modeling techniques, historical data, and assumptions. Energy scenarios in the literature cover a wide range of time horizons, from 20 to more than 100 years (Goldemberg 2000).

Figure 1 depicts that different types of scenarios can be distinguished by its frame and/or its target (Hamrin et al. 2007).

In the academic literature, in terms of typology, scenarios are classified in "Predictive", "Explorative" and "Normative" categories. The aim of Predictive scenarios is to make an attempt to predict what is going to happen in the future. BP and ExxonMobil Global energy scenarios are devoted to this category (Table 1).

The goal of Explorative scenarios is to explore situations or developments that are regarded as possible to happen. WEC and Shell energy scenarios are Explorative scenarios.

Normative scenarios focus on achieving a specific goal in the future. Greenpeace and IEA Bridge scenarios belong 


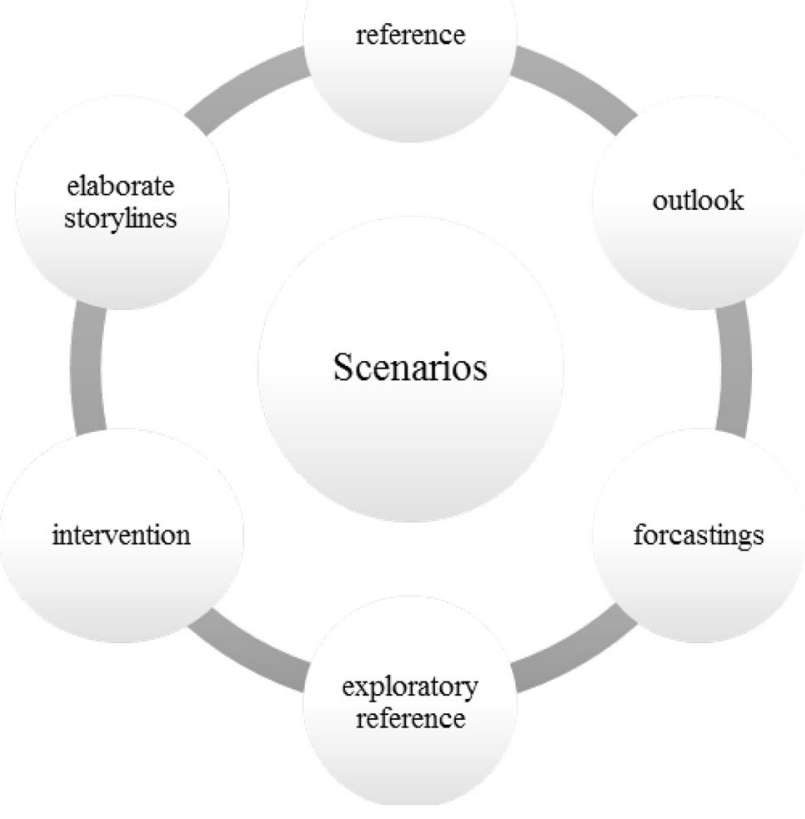

Fig. 1 Different frames of scenario (Hamrin et al. 2007)

to this category (Börjeson et al. 2006; Mietzner and Reger 2005; Glenn and Gordon 2009).

The following scenarios are reviewed in this paper:

Scenarios mentioned in Table 1 include the key factors such as demand, supply, energy intensity, and environmental issues, which are usually described by data analyzing and techniques to assess the effect of shifts and rapid developments in the global energy market. The mentioned scenarios are also different in their viewpoint on the future of energy in the term of policies, foreign relations, economic growth, and technological development.
As shown in Table 1, future energy scenarios have a time frame and a framework for scenario building. Global energy scenarios are classified in some categories in terms of the framework including Storyline (Shell), Outlook (ExxonMobil and BP), Outlook and Intervention (IEA and Greenpeace) and Exploratory and Reference (WEC).

\section{Shell (Global Energy Scenarios by 2050)}

According to Shell scenario, people are beginning to realize the importance of energy in their lives, which can be either destructive or helpful. Do people have to decide what they value most? - their health, environment, community, and future of their children, themselves and the planet itself or the blind economic targets-these deeply personal fears and hopes would highly affect the targets for the future of energy (Shell 2011).

\section{Blueprints}

The Blueprints and scramble scenarios are predicted in terms of how people would decide, and their decisions interact with the future of energy sector (Shell 2011).

"Blueprints describe dynamic collation of interests" (Shell 2011). Blueprints do not reflect the same causes and aims or interests but the unity and collaboration in the environmental concerns, energy supply, controlling rapid demand for energy are the major factors at work.

This scenario is not based on a universal collaboration of interests but a collaborative desire for survival. This scenario describes a world where collaborative concerns and fears make alliances and consensus to satisfy parallel targets and concerns.

Table 1 Main characteristics of the scenarios reviewed

\begin{tabular}{llllll}
\hline Sponsor & Scenarios & Classification & Framework & Timeframe & Authorship \\
\hline Greenpeace & Revolutionary & Normative scenarios & Outlook, intervention & 2009-2050 & International NGO \\
IEA & Bridge & Normative scenarios & Outlook, intervention & 1990-2030 & Global Policy Agency \\
Shell & Blueprints scramble & Explorative scenarios & Storyline & $2000-2050$ & Energy Corporation \\
WEC & Modern jazz unfinished & Explorative scenarios & Exploratory reference & $2014-2060$ & Global Policy Network \\
& Unfinished symphony & & & & \\
BP & Hard rock & & & 1990-2035 & Energy Corporation \\
ExxonMobil & Outlook baseline & Predictive scenarios & Outlook & 2000-2040 & Energy Corporation \\
\hline
\end{tabular}




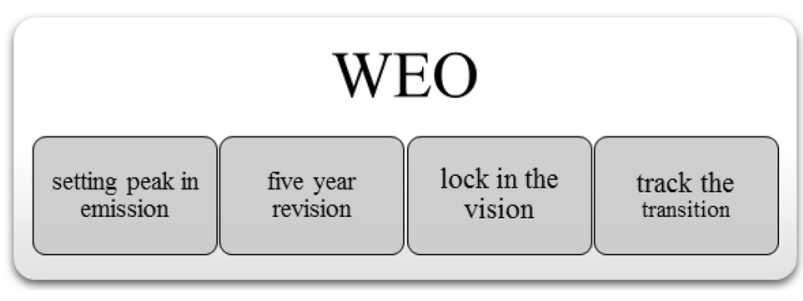

Fig. 2 World energy council's scenario pillars (IEA 2015)

As a result of this scenario, carbon intensity lowers and carbon management practice spreads and carbon markets become more efficient; electrification in transportation and other industries using electric vehicles highly directs the global industries to more environmental sustainability.

\section{Scramble}

"Scramble focuses on national energy security" (Shell 2011). In this scenario, ensuring energy security drives policymakers to rely on their internal capacities and their own energy supply in the near future and their allies. This approach puts much emphasis on local sources of energy and a significant increase in biofuels and coal supply.

Despite rhetoric actions, collative action on climate change would be more pronounced in the future. The demand-side policy is not pursued meaningfully until leakage in energy supplies and environmental policy is not addressed until climate events stimulate political responses. Events and decisions drive late but severe answers to emerging climate change and other events lead to a temporary slowdown in the events and carbon emissions rate moderates (Shell 2011).

\section{IEA (World Energy Outlook-2015)}

This report analyzes the energy sector's effect on climate change and the environment with regard to 21 st conference of the parties on global climate change in Paris. COP21 is being submitted by many countries throughout the world. The governments submitted to act in the full extent what is necessary to achieve. The two-third of world's greenhousegas emissions resulting in the energy sector means that pledges made in COP21 must bring deep cuts in the energy sector-related emissions, and hence, the importance of the energy parameter in the environmental equations is the key factor in this report.

The bridge scenario is based on intended nationally determined contributions (INDC) pillars mentioned in Fig. 2 and set a shorter-term future, 2020 instead of 2030 to meet
COP21's goals. The bridge scenario highly stands on the increase in fuel and energy efficiency in industry, building and transport sectors, progressively reduce the use of the least-efficiency coal-fired power plants, investing in the renewable energy technologies, phasing out of fossil fuels subsidies to end-users by 2030 and reducing methane emissions in the oil and gas productions (IEA 2015).

\section{World Energy Council (World Energy Scenarios-2016)}

WEC is monitoring the satisfaction of energy demand with fossil fuels since the 1970s and predicted a new world of energy in the future. These divergent trends and sources that are fundamentally different create a new world for the energy industry of lower population growth, new technological developments, greater environmental challenges and a shift in geopolitical and economic power. These trends will reshape the economy of energy which is called the grand transition. Studying the way that the following parameters interact with each other is described in three scenarios, i.e., Modern Jazz, Unfinished Symphony and Hard Rock (WEC 2016) (Fig. 3).

\section{Modern Jazz}

Modern Jazz describes the situation in which the market takes the main role in the energy industry. This scenario illustrates a world of growing economies, rapid technological developments like digitalization that not only changes the work style but also changes people's lifestyle. In this scenario, the economic and geopolitical shift to Asia is well-emphasized. Energy costs are reduced due to the developments on the energy supply side, and there is greater access to energy for all (WEC 2016).

\section{Unfinished symphony}

In this scenario, the world is "ticking on the same clock" and reaches a resilient and global low carbon energy industry. There is a global understanding on environmental and global economic issues, and global institutions and national governments support to technologically enable the countries involved. There will be relatively high and sustainable economic growth and high-level infrastructure investments.

Rebalancing the global wealth throughout the north to south, supporting for a broad-based international governance structure covering security, environmental and energy matters and strong networking policies and technologies for 


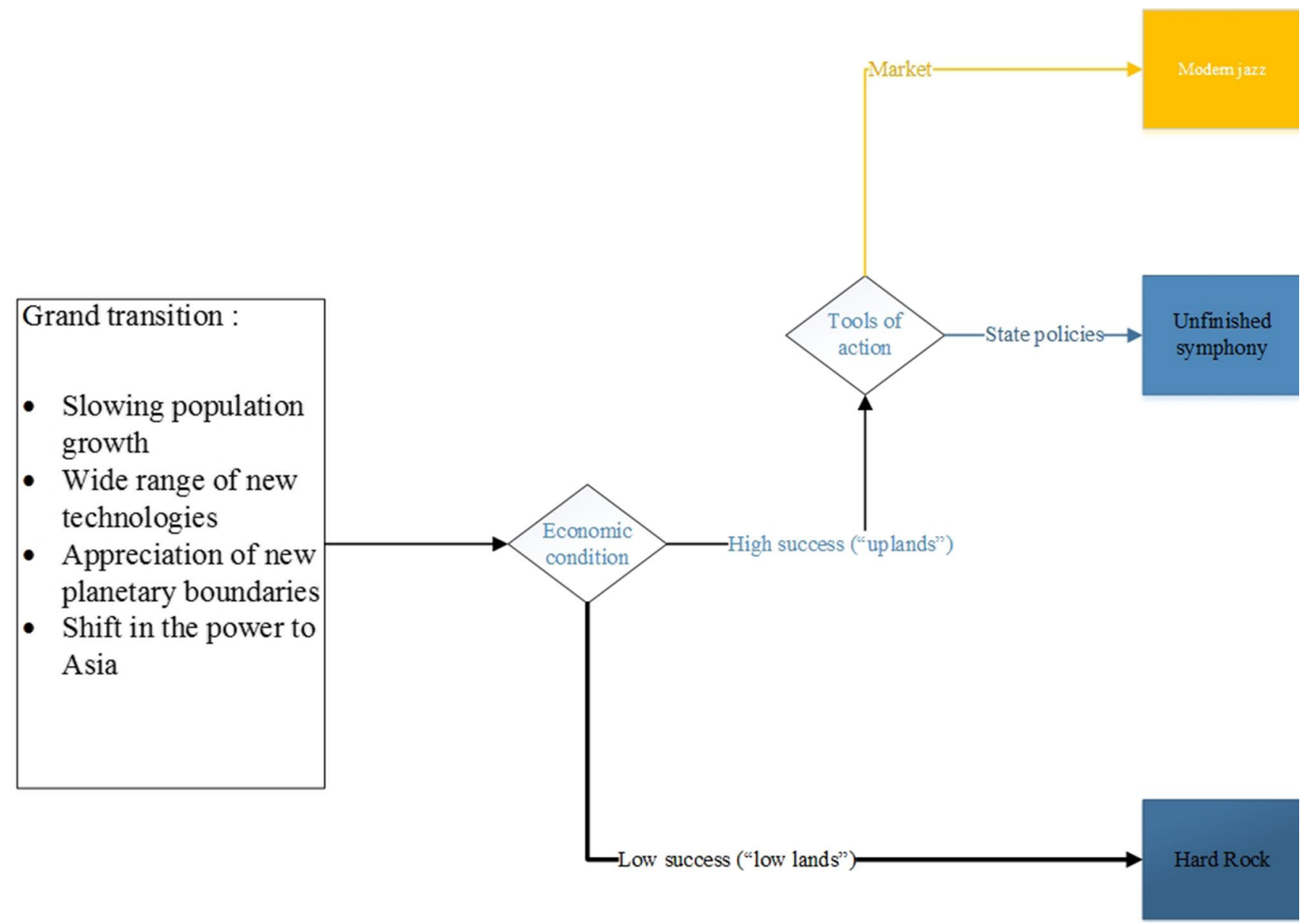

Fig. 3 Uncertainty over the trends of energy in the grand transition (WEC 2016)

carbon efficiency are other characteristics of this scenario (WEC 2016).

\section{Hard rock}

This scenario portrays a shattered world of a divergent set of economies, energy and environmental outcomes supported by nationalist approaches and interests. This viewpoint prevents countries from efficient collaborating at the global level, especially in the climate change sector.

In this scenario, technologies would only be developed within the framework of national interests, which declines productivity and causes slower economic growth as compared to the other two scenarios. The self-centering governments are the dominants on political campaigns. The low investment, volatile costs, and win-lose policies lower energy efficiency and security throughout the world and raise inequality and poverty between developed and developing economies (WEC 2016).

\section{British Petroleum (BP Energy Outlook-2017)}

The global energy industries are changing, and the traditional demand sector is overtaken by fast-growing markets like China and India. The mix of the energy consumption portfolio is also changing, driven by technological developments and environmental concerns. Rapid economic growth in emerging economies doubles global GDP, and more than 2 billion people would be released from poverty and low incomes. This prosperity growth increases energy demand around 30\%, which shows the necessity of rapid improvement in the energy efficiency sector.

The crude oil and natural gas dominance in energy supply provides half of the additional demand, and the renewables meet the remaining demand. The natural gas sector grows more quickly than the other two fossil fuels (crude oil and coal) led by shale gas beating coal as the third rank in energy supply. Higher energy efficiency, new technologies, and electrification in the transport industry lower the growth of oil demand. This may cause low-cost producers to take the advantage for more 
Fig. 4 Necessities of decarbonization of the energy sector

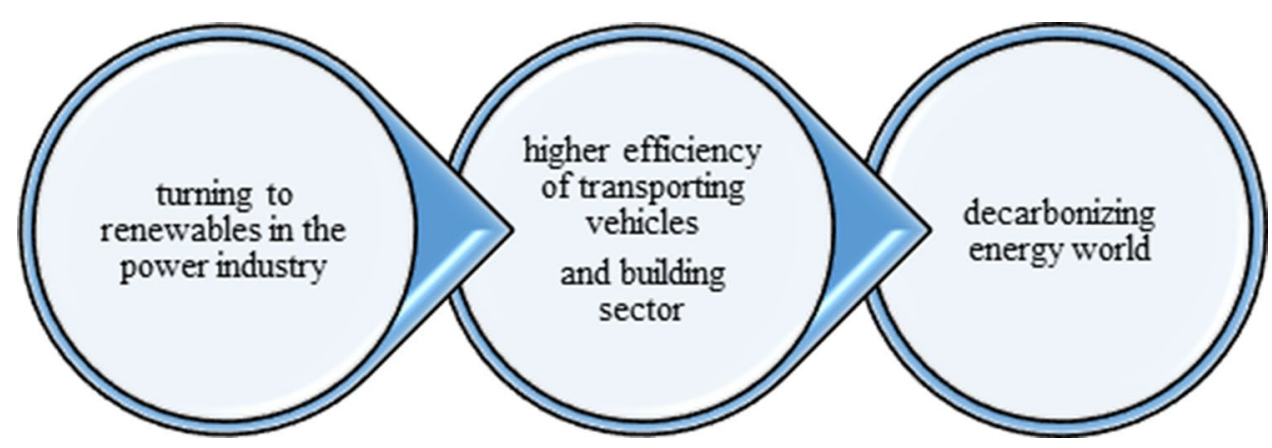

share of the market. The renewables are the fastest-growing resources, quadrupling over the next 20 years due to their competitive advantages and the decrease in carbon emissions (BP 2017).

\section{ExxonMobil (2017 Outlook for Energy: a View to 2040)}

ExxonMobil's energy outlook by 2040 illustrates a global view of energy demand and supply based on long-term investments and highlights the world's access to sufficient energy supply while reducing carbon emissions to address climate changes.

By the year 2040, World's population is expected to reach 9.1 billion, up from 7.3 billion today. Over the same period, global GDP doubles, with non-OECD as particularly having the high share of this astonishing growth. Expansion in the economy and industry increases energy demand by about $25 \%$ by 2040 ; global energy demand mix secures mostly $(60 \%)$ by the oil and natural gas and about $25 \%$ from nuclear and renewables (ExxonMobil 2017).

\section{Greenpeace and European Renewable Energy Council (Energy Revolution-2015)}

Greenpeace-Energy [r]evolution scenario is very optimistic with respect to renewable energy supply. In this scenario, the global energy future is described with features such as sustainable energy supply, decarbonized economic prosperity and a sharp decline in energy intensity by 2030 . This scenario makes it possible to keep the emissions below the 40 gigatons (IEA 2015).

The energy revolution scenario "ER" decarbonizes world energy sector by 2050 in the terms of higher energy efficiency and alternative energy sources like renewables. Global carbon emission stabilizes near 2020, and a steady reduction in emissions causes about zero by 2050 . ER scenario phases out fossil and nuclear portfolio as fast as technically possible. By 2050, the world's energy emission sum is 667 gigatonnes far beyond the 1000 gigatonnes of "safe" redline of the IPCC report. The main necessity to reach this amount of reduction mentioned in this scenario is shown in Fig. 4 (EREC 2012).

\section{Comparative analysis of global energy demand by scenarios}

The energy demand does not necessarily include only final consumption, and it also includes the amount of energy loss in the production, conversion, transition and distribution processes. Hence, the demand is highly dependent on the efficiency in transition, conversion, and consumption (Abbaszadeh et al. 2013).

Energy demand management plays a key role to control energy supply and environmental issues caused by energy consumption's pattern such as carbon emission. The global demand for energy is usually divided into four sections, i.e., Transportation, Residential, Industry, and Electricity. In this paper, demand of each section is analyzed separately.

\section{Transportation sector}

Energy demand for transportation can be measured by the fuel consumed in private, public and commercial sectors including railroads, maritime transportation, aviation, and roads.

Due to combustion's low efficiency and high dependency on economic growth, which is boosting rapidly in upcoming decades, transportation plays an important role in the future of energy demand. The technological growth in the transportation sector and high potential of energy auditing and optimization would reduce the amount of consumed energy in this sector or would turn energy to less-contaminating resources such as renewables, nuclear, hydrogen fuel, biofuels (Fig. 5).

Transportation is a major sector among end-users of energy. Given the significant growth of GDP and economic prosperity in the emerging economies, energy demand for this sector will experience an increasing trend. The 


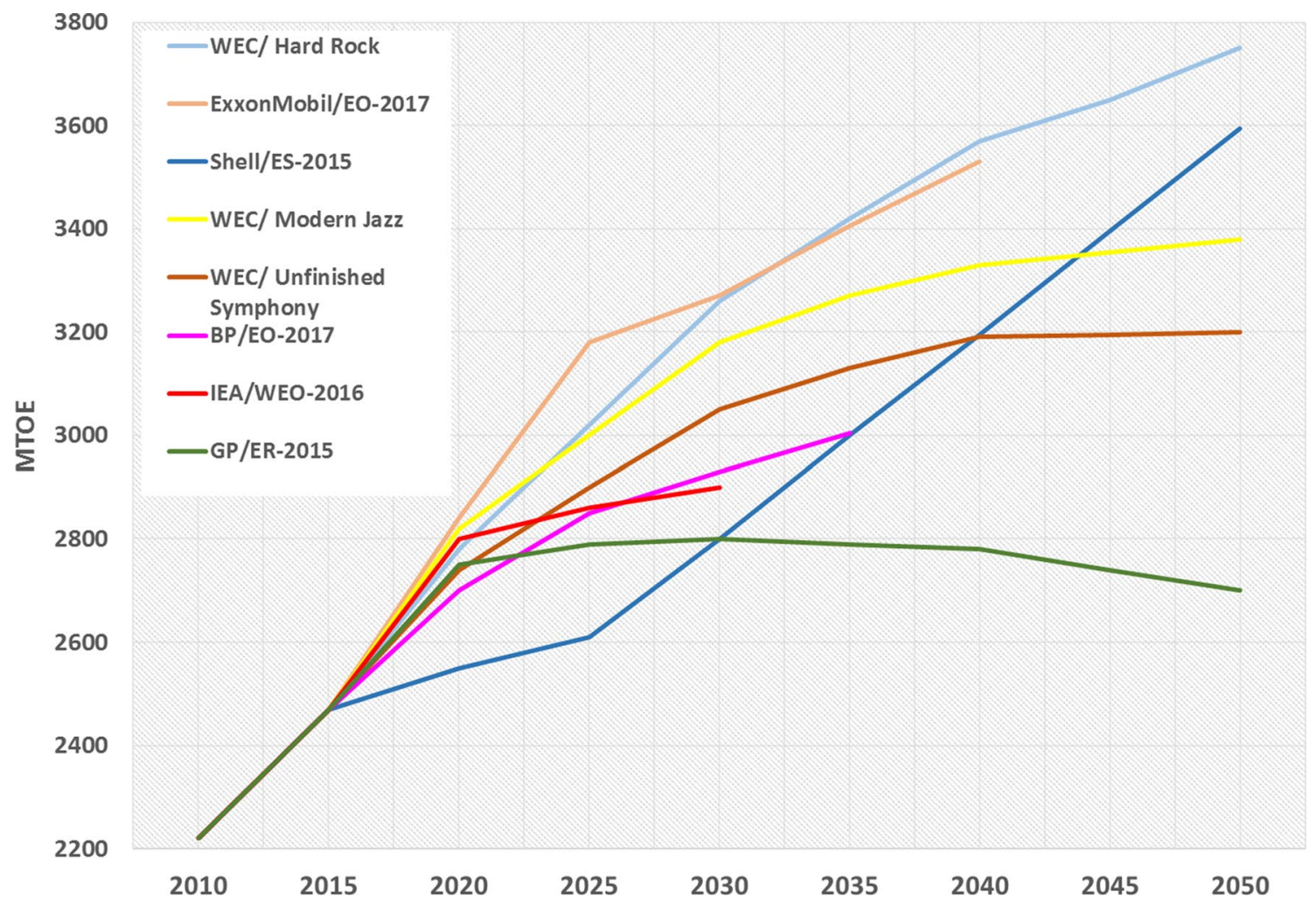

Fig. 5 Global energy demand in transportation sector

significant increase in the number of light vehicles with low efficiency causes more energy demand rates by 2015-2030.

Hard Rock and Scramble are less efficient energy scenarios because of strict national policies and energy security concerns which will increase the growth rate of energy demand. In the scenario Gp/ER because of the total decarbonization, energy trend is decreasing after the 2020 (Shell 2011; Greenpeace 2015; IEA 2015; WEC 2016; BP 2017; ExxonMobil 2017).

\section{Industry sector}

Industrial development increases the global energy demand, especially in Iron and steel, chemical, petrochemicals and oil refined products, non-metallic mineral producing, transport equipment, machinery, food and tobacco, paper, pulp and print, wood and wood products, construction and textile and leather industries.

In the energy revolution scenario, energy demand in the industry sector declines rapidly because of applying massive decarburization techniques.

According to Fig. 6, the average growth rate of energy demand in the industry sector is decreasing beyond 2025 because of a significant volume of electrification (electrical vehicles, digitalization, etc.).
According to Fig. 6, energy demand is highly dependent on governmental policies and foreign affairs, economic systems and how they respond to environmental issues. Thus, each scenario predicts its unique numeric output for the energy demand (Shell 2011; Greenpeace 2015; IEA 2015; WEC 2016; BP 2017; ExxonMobil 2017).

\section{Residential sector}

The global energy demand in the Residential sector is increasing but at a moderate growth rate. Most of the scenarios show that the energy savings in buildings and residential sector have a major impact on reducing energy demand (Fig. 7).

\section{Electricity demand}

Electricity is the most important demanding sector over the upcoming decades and is the most important role-player as a response to environmental and emission issues. Electricity demand is increasing because of its less carbon contamination and higher efficiency compared to the combustion engines.

Although the electricity is mainly generating by natural gas, petroleum products and coal-fired power plants, it has a great potential of turning to alternate non-contaminating 


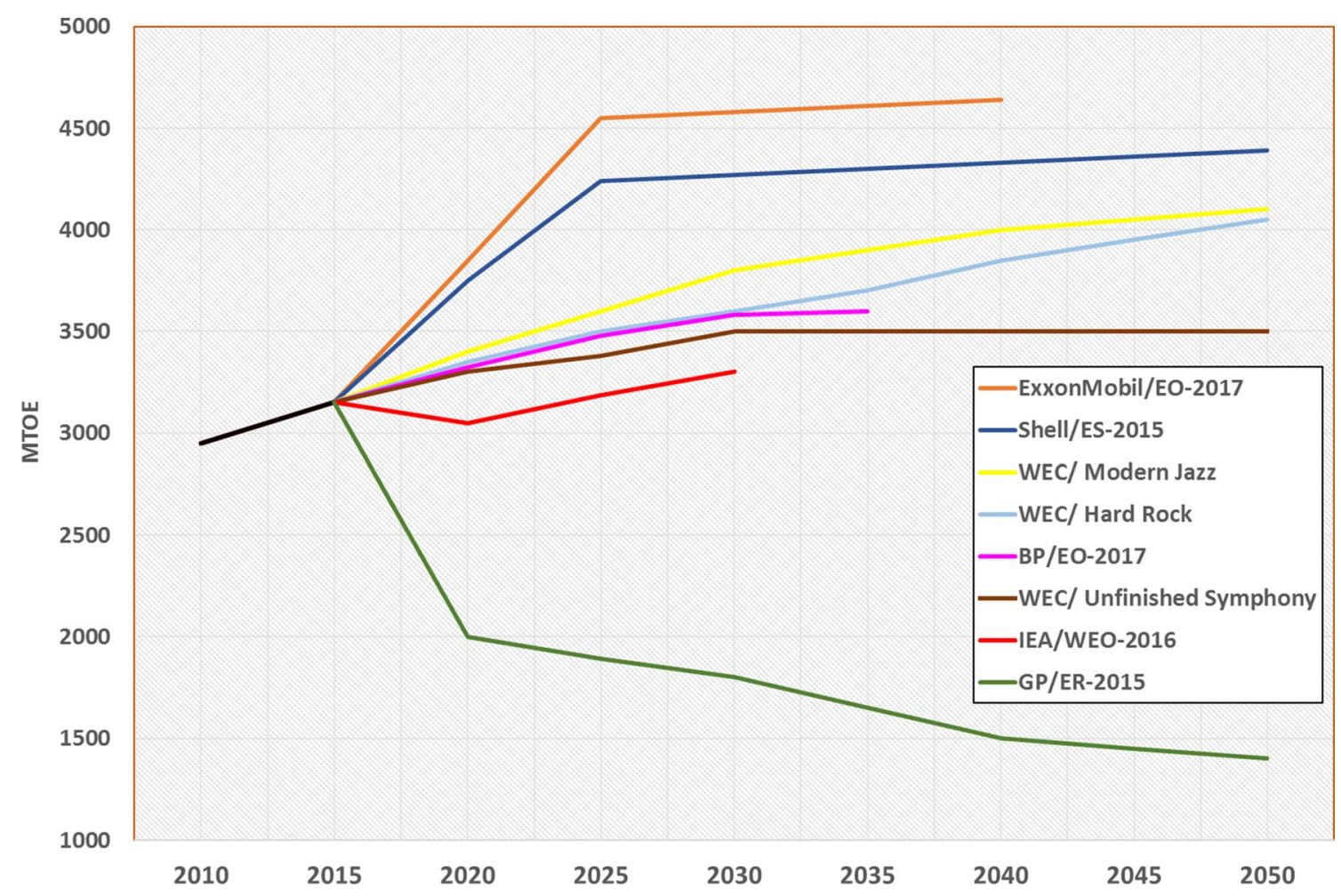

Fig. 6 Global energy demand in industry sector

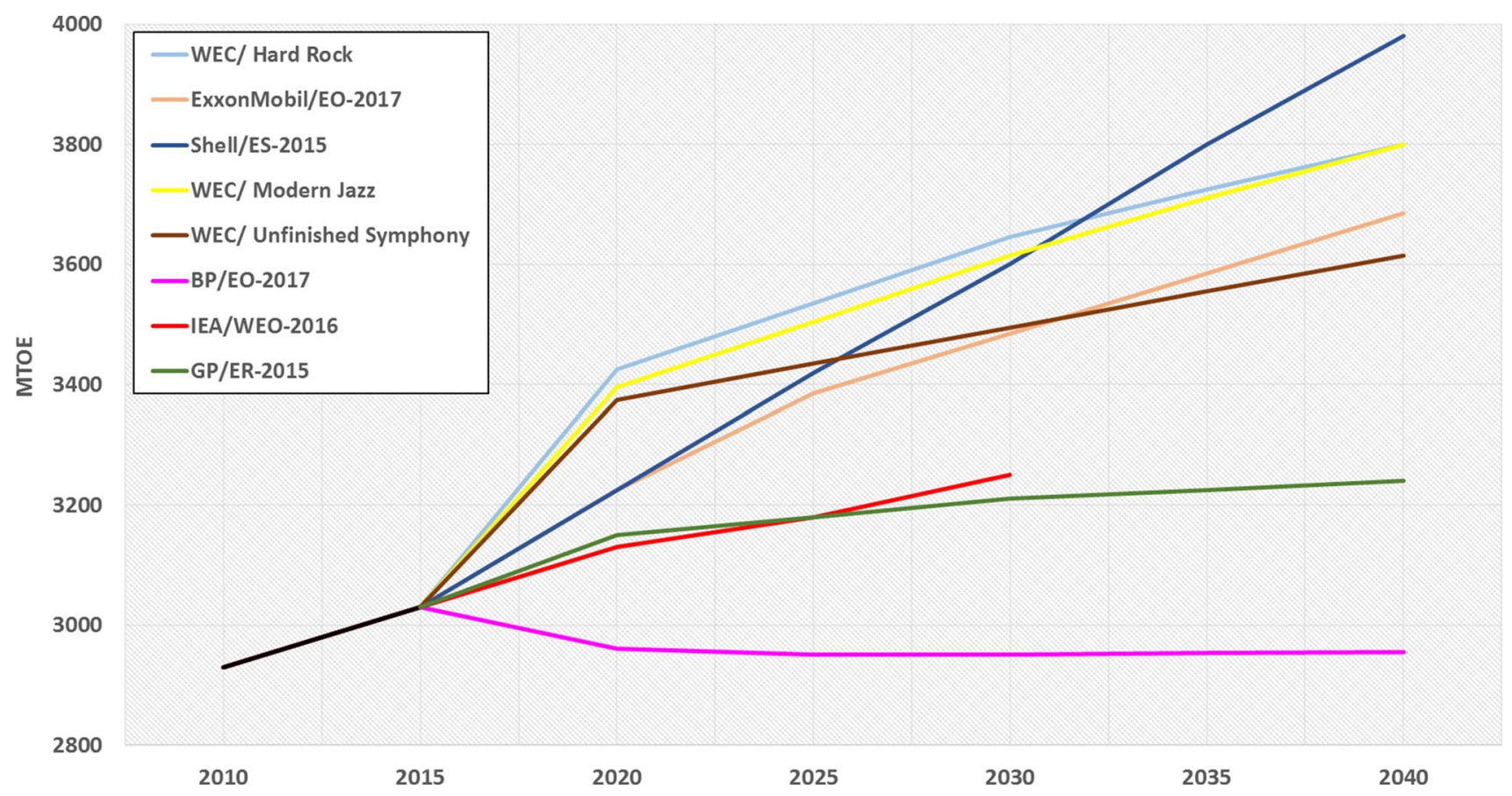

Fig. 7 Global energy demand in the residential sector

power sources such as hydroelectricity, wind, photovoltaic, solar thermal, geothermal, fuel cells, biofuels, and hydrogen (Abbaszadeh et al. 2013).
Figure 8 visualizes that the decarburization trend (ER scenario) leads to rapid growth of demand for electricity Furthermore, scenarios with a free economic system approach 


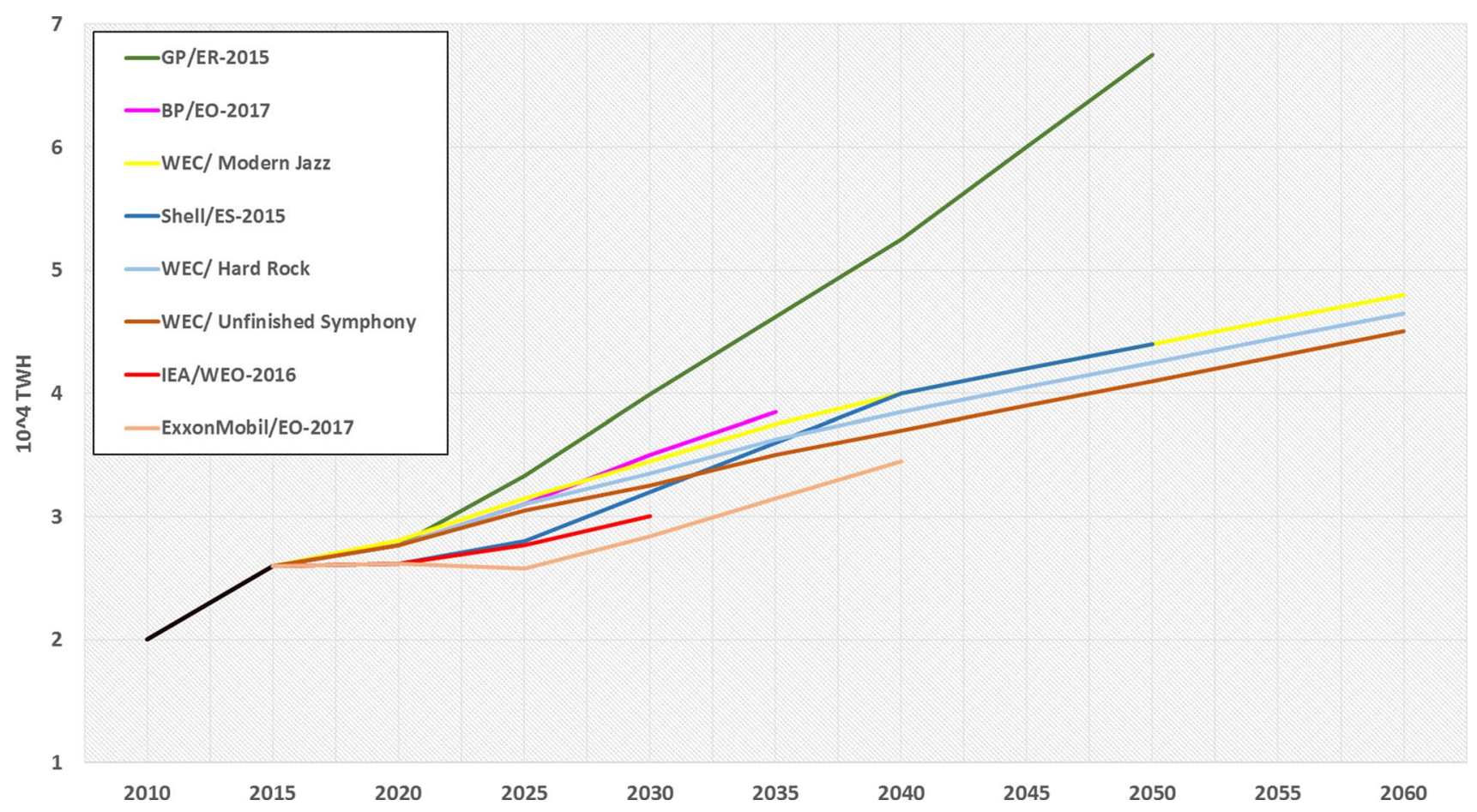

Fig. 8 Global demand for electricity

(Modern Jazz) and open-access technologies (Unfinished Symphony and Shell's Blueprints) project a significant increase in electricity demand caused by technological development and cost effectiveness of renewable electricity resources. Development and industrialization of renewable power generation and environmental issues encourage more investments which leads to cost efficiency, hence contributing to renewable energy's greater share of demand portfolio (Shell 2011; Greenpeace 2015; IEA 2015; WEC 2016; BP 2017; ExxonMobil 2017).

\section{Comparative analysis of global energy supply by scenarios}

Each scenario represents an energy supply based on a unique trend over its parameters.

Figure 9 shows the paths predicted for the future global energy supply by IEA, BP, WEC, GP, ExxonMobil, and Shell.

The rise of energy supply predicted by global scenarios except the energy revolution of Greenpeace is based on the assumptions like technology development, investment in infrastructures, economic growth, price fluctuation (Goldthau 2016). In "GP" scenario, total energy supply decreases because of the rapid decarbonization plan worldwide and the governments' effort to achieve on the efficiency and develop renewable technologies.
Energy efficiency and renewables lead to lower energy intensity (Global Decarbonization) and as a result, global energy supply growth would be reduced as a response to the lower levels of energy demand.

Each of the scenarios shown in Fig. 9 has its own unique trend over the period (2015-2030) regarding its definitions, fundamentals, and the assumptions employed. BP/2017-EO and ExxonMobil 2017-OE are the reference outlooks which is the result of a single extrapolation forecasting or projection of the most common path of energy's future if current situation stays unchanged. GP/ER contains optimum desirable situation of the world energy system which is a green (decarbonized) energy world.

Blueprints, Modern Jazz and Unfinished Symphony are more desirable because of the collaborative approach over international affairs and open-access technologies. In these scenarios, economic growth is higher than the Scramble and Hard rock due to concentration on nationalist policies for solving energy issues that would restrict international participation and collaboration.

IEA-WEO also is a scenario with high desirability. Its purpose is to project the goals of the 21st international conference on climate change "COP-21", which is held in the Paris and seriously took the climate issues into account. Its successful forecasting output shows the effectiveness of decarburization in the desirable energy system projection (Shell 2011; Greenpeace 2015; IEA 2015; WEC 2016; BP 2017; ExxonMobil 2017). 


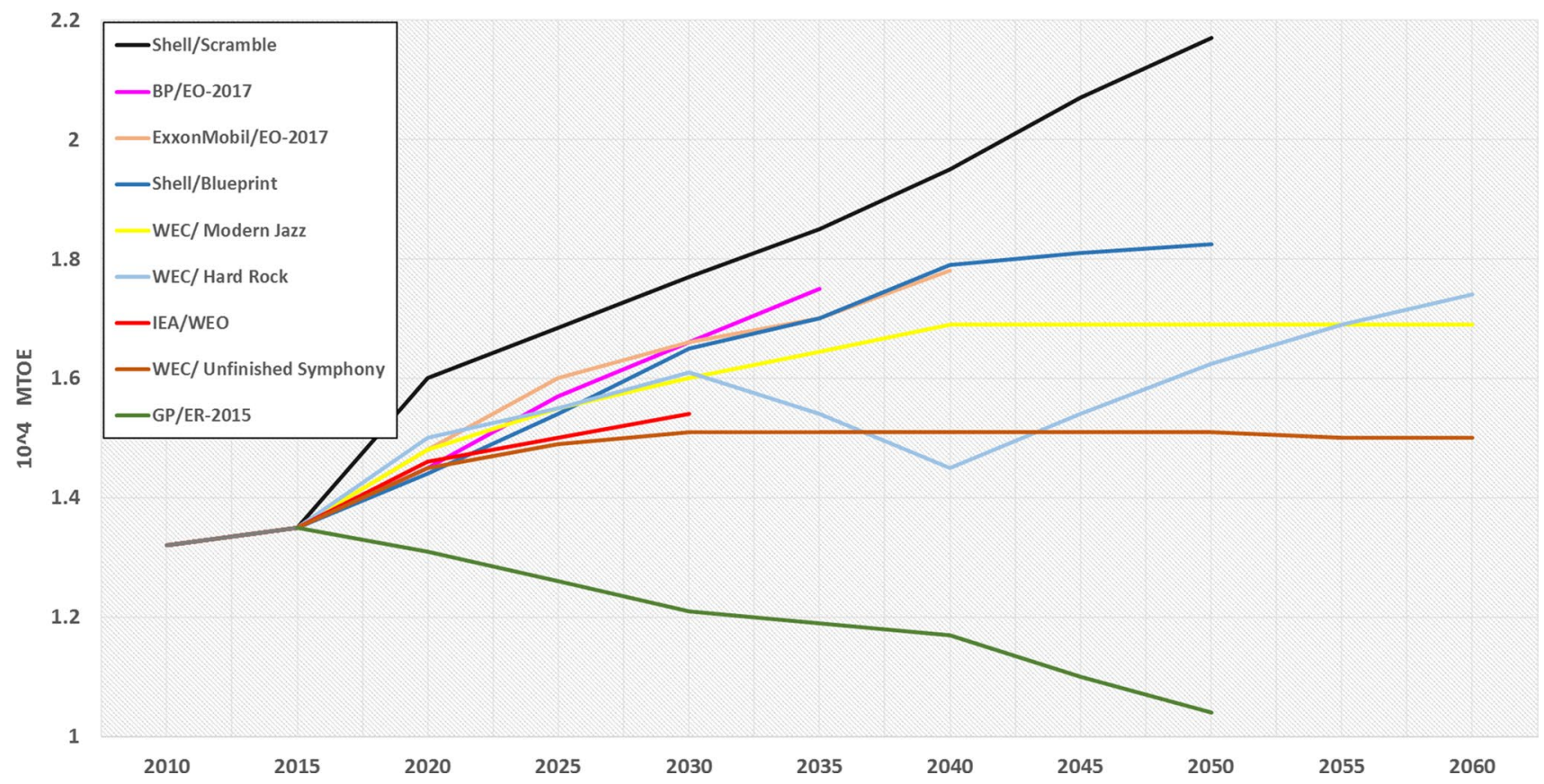

Fig. 9 Global energy supply in selected global energy scenarios (million tons of oil equivalent)

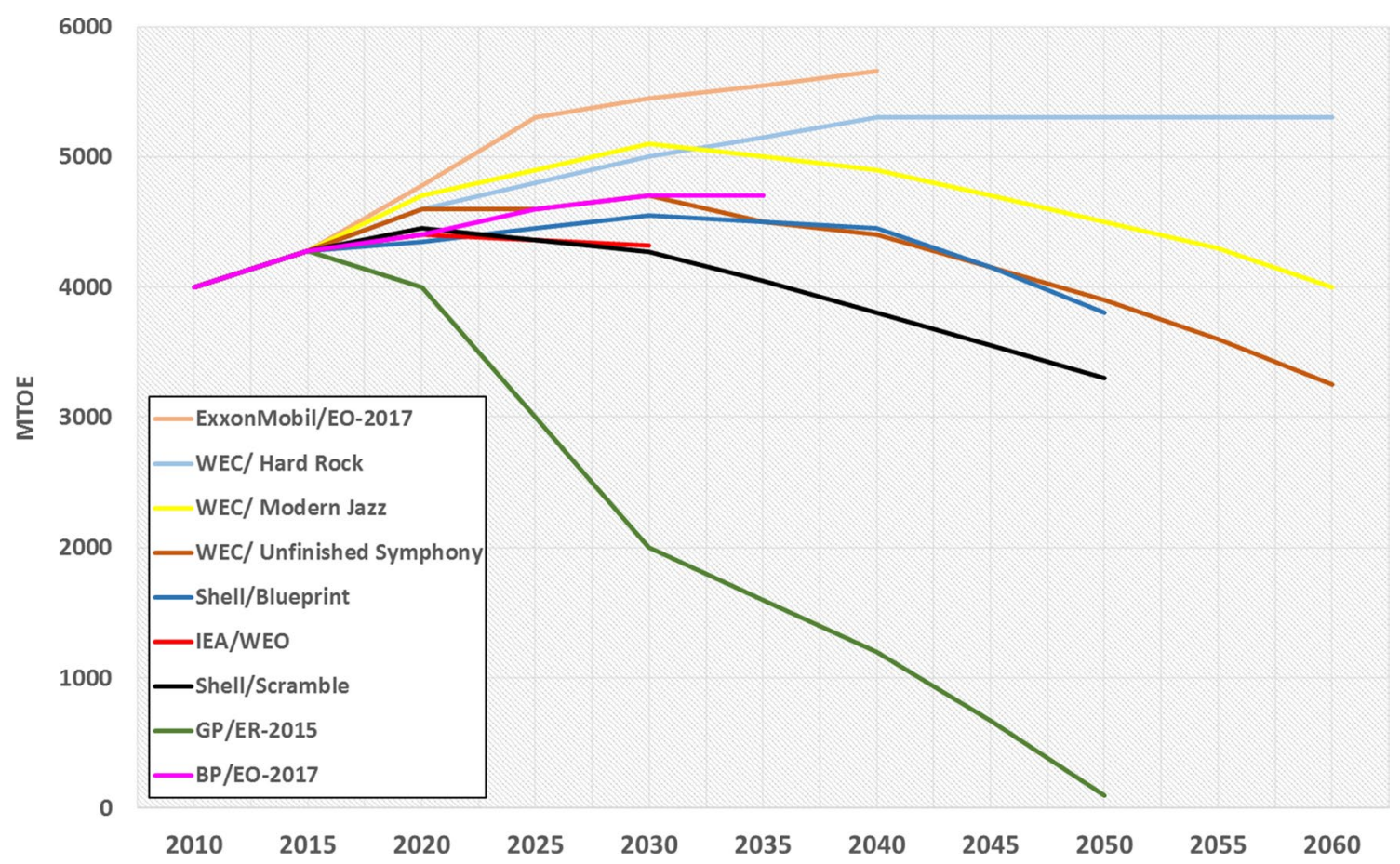

Fig. 10 Oil supply in selected global energy scenarios

\section{Crude oil}

Regarding its unique energy characteristics, particularly the high energy content, crude oil is a strategic commodity and plays a significant role in international politics as well as world economic growth. Its role in the economic growth of emerging countries has been increasing during the past three decades will remain strong in the foreseeable future.

Figure 10 illustrates that crude oil supply slowly increases during the period 2015-2030. Crude oil supply 


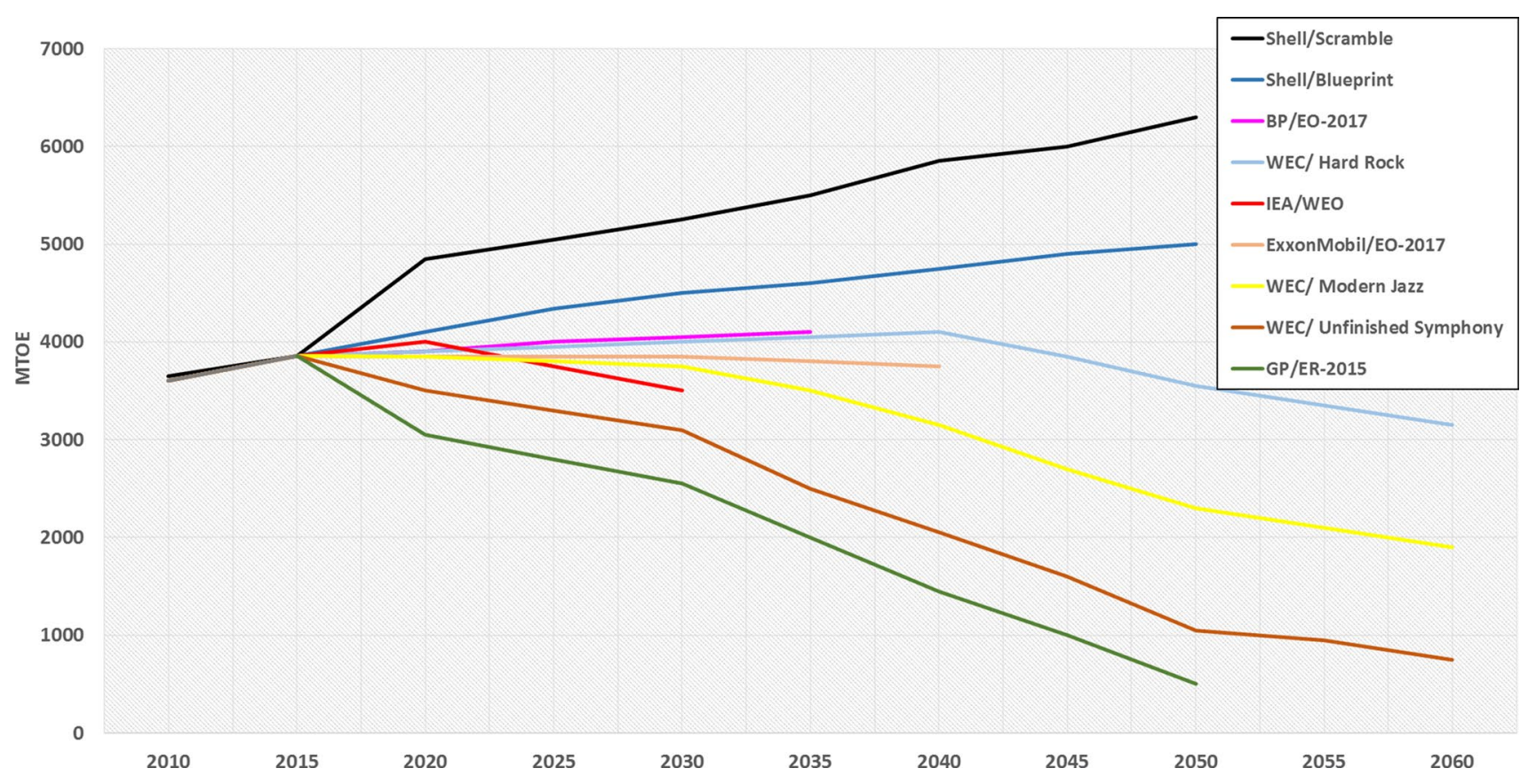

Fig. 11 Coal supply in selected global energy scenarios

reaches its peak by the 2030's and then it will slowly lose its share of the market to its alternative energy resources (Shell 2011; Greenpeace 2015; IEA 2015; WEC 2016; BP 2017; ExxonMobil 2017).

\section{Coal}

High carbon coal is one of the cheapest resources of power generation which is widely used in developing and nonOECD countries as the main source of energy.

The coal supply is on its downfall in the upcoming decades because of its high carbon contamination, which is two times more than the natural gas per kWh (Fig. 11).

Coal demand is decreased in the studying period. In the Scramble and Hard Rock scenarios, the coal demand as a local energy resource increases in the future because of nationalism and strict foreign policies. In other scenarios, due to international collaborative approach, decarbonization and free-access technologies that lead to coal alternations such as biomass, gas, renewables investments in coal-based industries and its supply will be reduced (Shell 2011; Greenpeace 2015; IEA 2015; WEC 2016; BP 2017; ExxonMobil 2017).

\section{Natural gas}

In line with some views of gas as the bridge to renewable energy sources, natural gas demand is generally projected to grow in the near term in almost all scenarios. Less pollution and high thermal convention are the advantages of gas as source of energy. Hence, power generation industries rapidly grow as compared with other fossil energy producers.

Data mentioned in Fig. 12 show that the average gas supply in various scenarios is increasing by 2030. BP2017-EO and ExxonMobil-2017-EO report an increase in natural gas demand and supply as an alternative resource for the supply of coal and other low carbon efficiency resources. Energy security and open-access technology are the most important driving forces in the gas market.

Gas supply growth is faster in the Unfinished Symphony, Modern Jazz, and Blueprints because of international collaborative affairs and policies related to the strict nationalism-based Scramble and Hard Rock scenarios. Moreover, because of the strict coal-controlling policies, natural gas supply is rapidly increasing during this period (Shell 2011; Greenpeace 2015; IEA 2015; WEC 2016; BP 2017; ExxonMobil 2017).

\section{Nuclear energy}

Despite its costly maintenance and technically complex controlling system, the nuclear energy is the highest efficient energy production through power generation methods.

Figure 13 illustrates the trend of energy supply by the nuclear source, which is mostly electricity. According to Fig. 13, the average nuclear energy supply in various scenarios is increasing. Shell and WEC scenarios show the effect of both international open-access technology and 


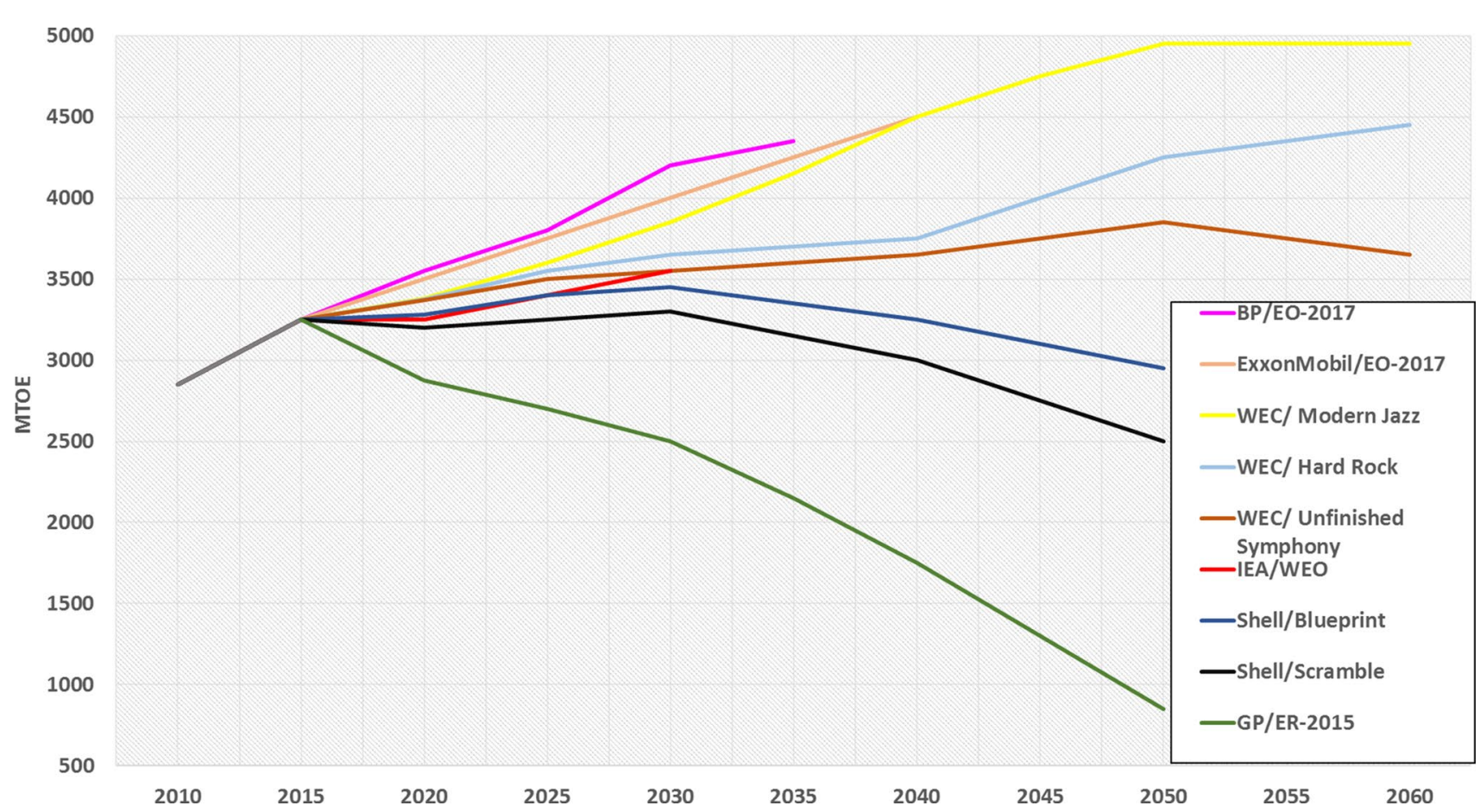

Fig. 12 Natural gas supply in selected global energy scenarios

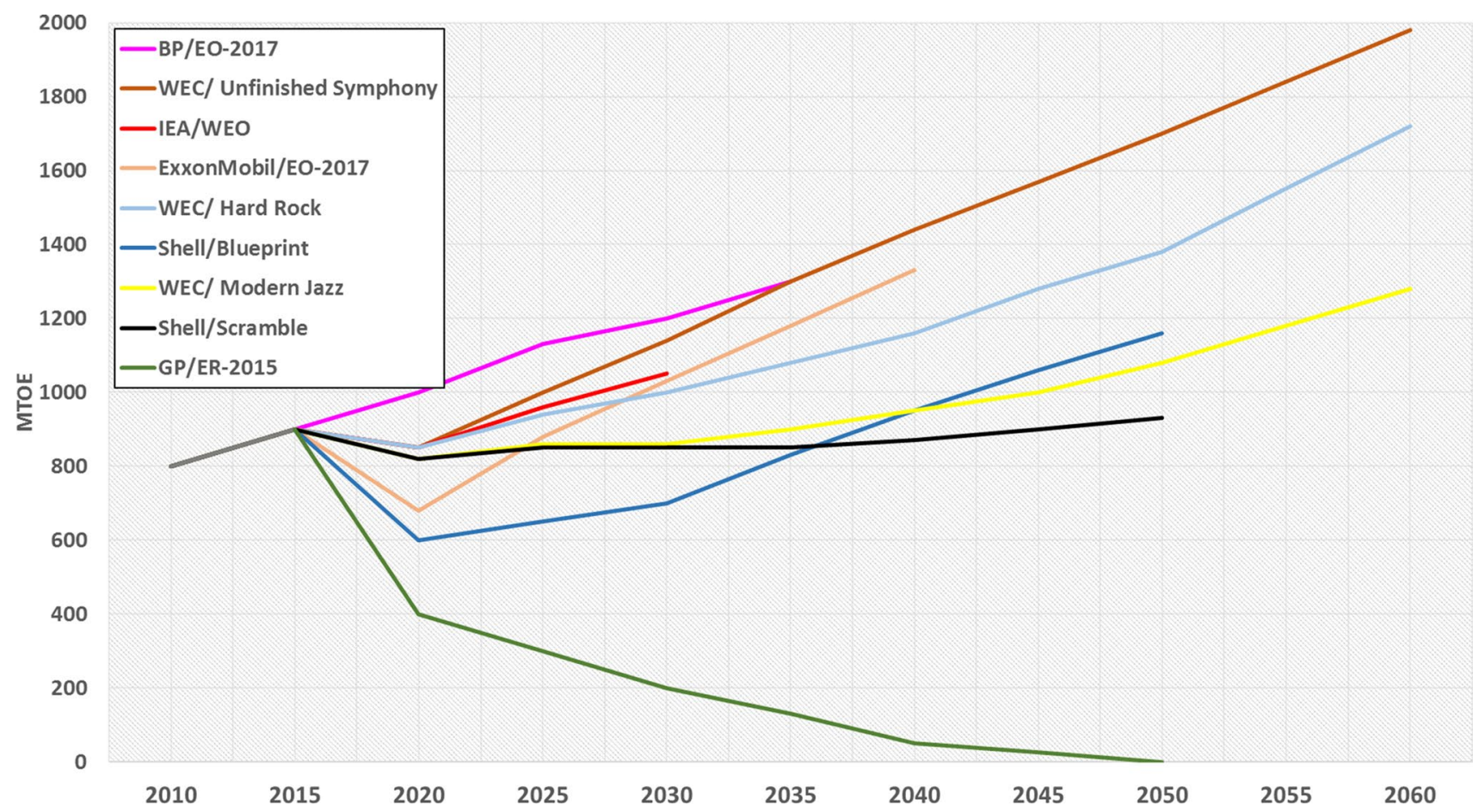

Fig. 13 Nuclear energy supply in selected global energy scenarios

local interests on the advancement of nuclear production. However, ER projects present a decreasing trend of nuclear energy because of its environmental effects and uncontrollably destructive potential (Shell 2011; Greenpeace 2015; IEA 2015; WEC 2016; BP 2017; ExxonMobil 2017). 


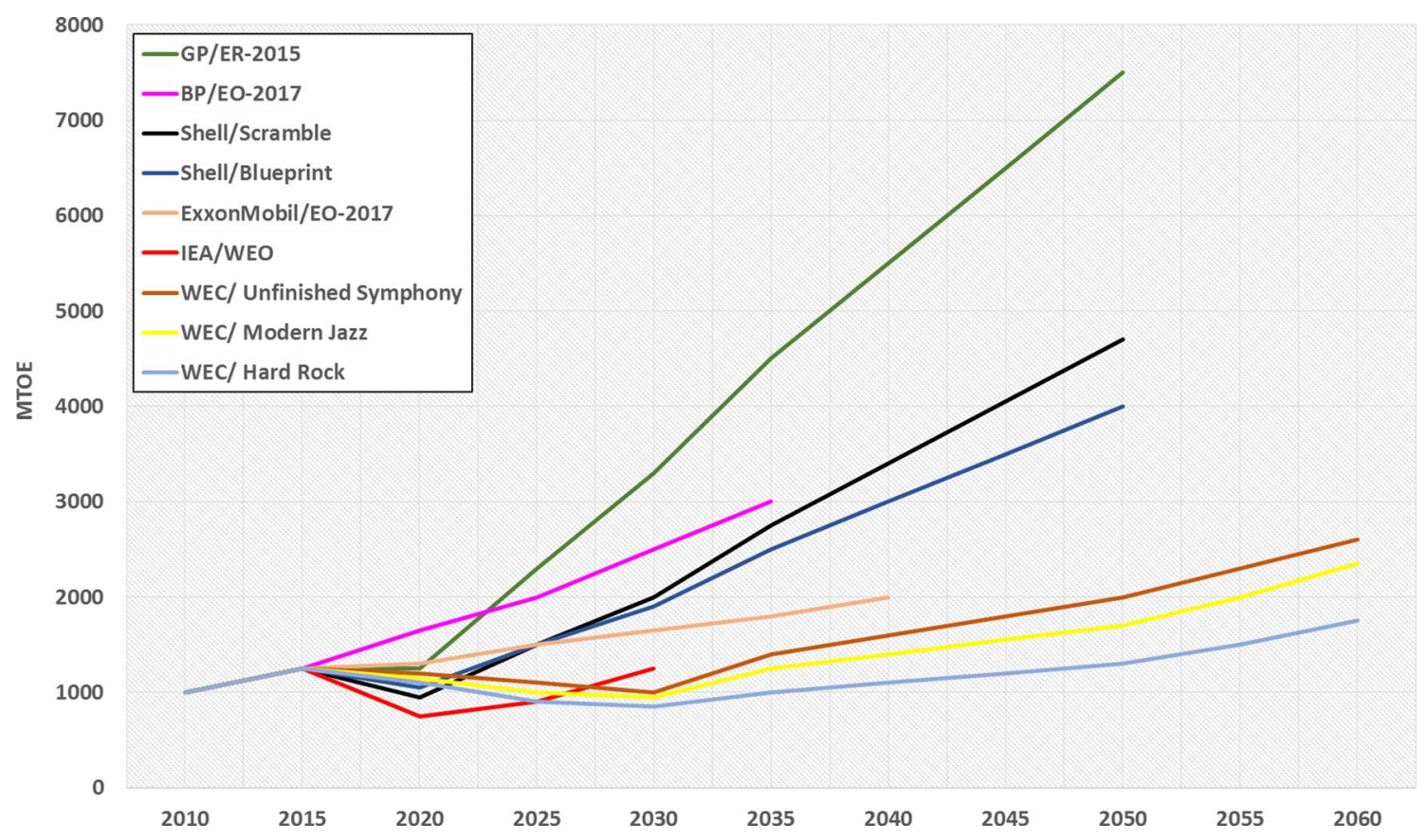

Fig. 14 Renewable energy supply in selected global energy scenarios

\section{Renewable energy}

Renewable energy, unlike the public beliefs, is an ancient power resource used in ancient Persian watermill and windmills and Roman-Greek solar concentrators which are invented many centuries ago (Bahrami and Abbaszadeh 2013). The origin of biofuel as a resource of energy dates back to about 150 years ago when the first hydro-electrical generation dams were built (Chaharsooghi et al. 2015).

Two major opposing trends are identifiable regarding the future of renewables. Small-scale RE technologies, such as solar power installed in buildings, are expected to expand and at the same time, large-scale centralized solar and wind power plants are expected to be developed for economic reasons. Significant improvements has already been made in this area (Johansson 2013; Kopetz et al. 2015).

The role of renewables in the world energy markets can be characterized using several different indicators, one of which is the share of total global energy supply (Bahrami and Abbaszadeh 2013). It should be noted that the renewable portfolio contains solar photovoltaic and solar thermal, geothermal, hydro energy, hydrogen technology (Fig. 14).

Global energy scenarios forecast a bright future for the renewables in the upcoming decades in which by 2030 about $18 \%$ of world energy needs can be provided by renewables (Gp-ER-2012). Open-access technologies seem to be the most important role-player in the field of renewables. This is due to the great performance of the scenarios (Blueprints, Modern Jazz, and Unfinished Symphony), which are analyzing international security of energy efficiency over the energy world.

The reduction of renewable energy supply during the period 2015-2020 is due to the decline in crude oil prices, which make the renewable energy less attractive as compared to fossil fuels. In all WEC scenarios, renewable energy supply continues its decreasing trend up to 2030 and then gradually rises until 2060 (WEC 2016).

Other scenarios predict an increasing trend of renewable supply after 2020 due to the higher economic desirability of renewables (Shell 2011; Greenpeace 2015; IEA 2015; WEC 2016; BP 2017; ExxonMobil 2017).

\section{Methodology}

In the existing academic literature, there are many debates about paradigm shifts, concerns, taxonomies and various approaches of foresight practices and methods (Boucher and Amara 1977; Masini 2001; Cuhls 2003; Voros 2003; Miles 2008; Glenn and Gordon 2009; Hafezi et al. 2018).

According to Popper (2008a, b), foresight methods are categorized as qualitative, quantitative or semiquantitative. Semiquantitative methods apply mathematical principles to quantify the subjectivity, rational judgments and viewpoints of experts such as cross-impact analysis and Delphi (Popper 2008a, b; Popper and Medina 2008).

This study applies cross-impact/structural analysis as a semiquantitative method. Using the existing literature on global energy systems, 40 drivers are identified. The drivers 
Fig. 15 Illustration of our fourstep method to reach global energy driving forces

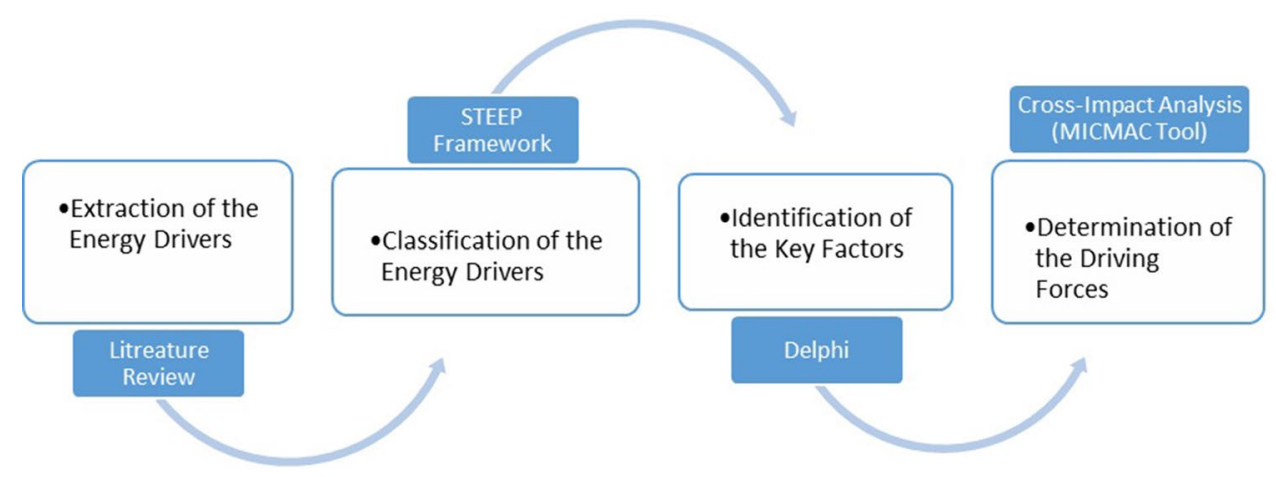

were then categorized into five groups as follows: social, technological, economic, environmental, and political.

In the next step, the key factors were extracted using the Delphi method through questionnaires and interviews with 40 academic professionals, experts in international institutions such as OPEC, and energy policy makers, based on the STEEP framework using mathematical and statistical analysis. In the final step, the application of cross-impact analysis identifies the driving forces of the global energy system using the MICMAC tool (Fig. 15).

\section{Identification of the global energy key factors}

The heart of scenario building is to identify the right key factors around which construct and influence the future environment (Bradfield et al. 2005; Schwartz 2012; Amer et al. 2013).

Forty key factors were selected by the research workers in this study. The key factors are classified in social, technological, economic, environmental and political categories as shown in Table 2.

\section{Determination of the global energy driving forces}

Driving forces are the key factors which have strong impacts on other key factors but are weakly affected by the others. In other words, driving forces represent all variables that can form future energy players individually or through interaction with other factors (Wack 1985; Pillkahn 2008).

Based on the methodology of future studies, driving forces are defined by cross-impact analysis. Cross impact analysis was originally developed by Gordon and Helmer in 1966, and since then it has been widely used as future research method (Gordon 1994; Bishop 2007). Cross-impact analysis is a method which contains a process of scanning possible futures to reduce uncertainties and investigates pairwise analyzing of listed events (Bradfield et al. 2005). Cross-impact analysis is a scenario design methodological approach in which mutual connection of a set of variables (descriptors) has been assessed by expert judgment (Culka and Society 2018). Cross-impact analysis is used to capture the inter-relationship between key influencing factors. The Delphi method is used to fill cross-impact matrix (CIM). The Delphi panel participants were asked about the conditional probability of occurrence of each cell, and an average of their answers was then placed in each cell after it was corrected by experts' view. This method has been widely used recently, and many researchers have attempted to make it more applicable (Pillkahn 2008; Amer et al. 2013).

Based on Delphi panel's judgments, the impacts of key factors on each other has been evaluated by variable MICMAC software (Fig. 16). ${ }^{1}$

This graph shows the extent to which the key factors are affected by each other at 5 levels, i.e., weakest, weak, moderate, relatively strong and strongest influences.

The analysis is performed on the basis of grading the direct relationship between parameters with using questionnaires which consist of the importance and the probabilities of driving forces (events) for both the present and future perspectives. The resulting matrix (cross-impact matrix (CIM)) is used as an input of the cross impact analysis process using MICMAC software (Godet 2000).

Cross impact analysis generates a quartet map divided into four quadrants (areas) representing four types of variables which are illustrated in Fig. 17. The difference between these variables lies in their influence and dependence, where the influential and dependent variables represent input and output variables, respectively (Alipour et al. 2017).

The distribution of factors within one of the four quadrants of the influence map infers distinct aspects of factor impact, and the evolution is based on varying levels of factor influence and dependence (Arcade et al. 1999). The horizontal axis of cross-impact matrix indicates the degree of dependency, and the vertical axis shows the extent of influence. Factors within Quadrant II, called driving forces or

\footnotetext{
$\overline{1}$ This figure is exported to word from MICMAC software as a result
} of this research. 
Table 2 Key factors of global energy scenarios in selected international studies

\begin{tabular}{|c|c|c|c|c|}
\hline Social & Technological & Economic & Environmental & Political \\
\hline Population growth & $\begin{array}{l}\text { Remaining technically } \\
\text { recoverable natural gas } \\
\text { resource }\end{array}$ & World GDP growth & Climate change & Global governance \\
\hline Aging population & $\begin{array}{l}\text { Remaining technically } \\
\text { recoverable tight oil } \\
\text { resource }\end{array}$ & Energy efficiency & Net $\mathrm{CO}_{2}$ emissions change & National energy policies \\
\hline Urban development & $\begin{array}{l}\text { Remaining technically } \\
\text { recoverable extra heavy } \\
\text { and bitumen resource } \\
\text { (EHOB RTRR) }\end{array}$ & Investment in infrastructure & Land use and access & $\begin{array}{l}\text { Geo-political relationships } \\
\text { and tensions }\end{array}$ \\
\hline Migration & $\begin{array}{l}\text { Remaining technically } \\
\text { recoverable conventional } \\
\text { crude oil }\end{array}$ & Financial shocks & Chemical pollution & $\begin{array}{l}\text { Changing power blocs } \\
\quad \text { (changing } P \text { ) }\end{array}$ \\
\hline Labor force growth & $\begin{array}{l}\text { Technology developments in } \\
\text { petroleum upstream }(T 1)\end{array}$ & $\begin{array}{l}\text { Emerging economies GDP } \\
\text { growth (Emerging E) }\end{array}$ & Carbon capture and storage & \\
\hline \multirow[t]{12}{*}{ Workforce productivity } & $\begin{array}{l}\text { Technology developments in } \\
\text { renewables }(T 2)\end{array}$ & Consumers behavior & & \\
\hline & $\begin{array}{l}\text { Technology developments in } \\
\text { nuclear }(T 3)\end{array}$ & $\begin{array}{l}\text { Global oil supply growth } \\
\text { (COP) }\end{array}$ & & \\
\hline & \multirow[t]{10}{*}{ Electric vehicles (EV) } & $\begin{array}{l}\text { Global gas supply growth } \\
\text { (GGSG) }\end{array}$ & & \\
\hline & & $\begin{array}{l}\text { Global coal supply growth } \\
\text { (GCSG) }\end{array}$ & & \\
\hline & & $\begin{array}{l}\text { Global renewable energy } \\
\text { supply growth (GRESG) }\end{array}$ & & \\
\hline & & Energy access and poverty & & \\
\hline & & GDP per capita change & & \\
\hline & & Crude oil price & & \\
\hline & & Natural gas price (NGP) & & \\
\hline & & US shale oil production & & \\
\hline & & Deep water shelf production & & \\
\hline & & $\mathrm{CO}_{2}$ prices & & \\
\hline
\end{tabular}

influent factors, are those that strongly drive the system's behavior but not controlled by it.

The most important driving force is the factor that has the highest influence and the least dependency, which is located in the upper left corner of the matrix. Factors in Quadrant I are called relay factors. Relay factors are both highly influential and highly dependent on other factors and thus represent unstable and emergent outcomes within global energy market. Relay factors play an important role in the future of the world energy markets if the driving forces they depend on have a significant change.

Factors within Quadrant III are called autonomous factors and have little influence or dependence on other factors and thus exert negligible influence on global energy systems behavior. Factors in Quadrant IV are known as result factors. Result factors have low influence, and their dependence is highly sensitive to the evolution of influent and relay factors (Fig. 17). ${ }^{2}$

According to Fig. 17, investment in infrastructure is an influential factor in reshaping the future of international energy markets. Similarly, financial shocks such as international financial crises act as a driving force in the future of energy markets. According to the position of key factors on Quadrant II of the cross-impact matrix, investment in infrastructure has the highest impact on other factors, and population growth rate is the weakest factor among driving forces.

Population, consumer behavior, and energy efficiency are among the most important driving forces according to the findings of this research work. Among different technology key factors, only technology developments in renewable (T2) and technology developments in petroleum upstream sector (T1) are identified as driving forces.

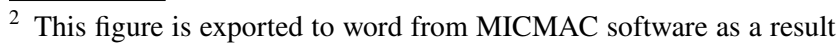
of this research. 


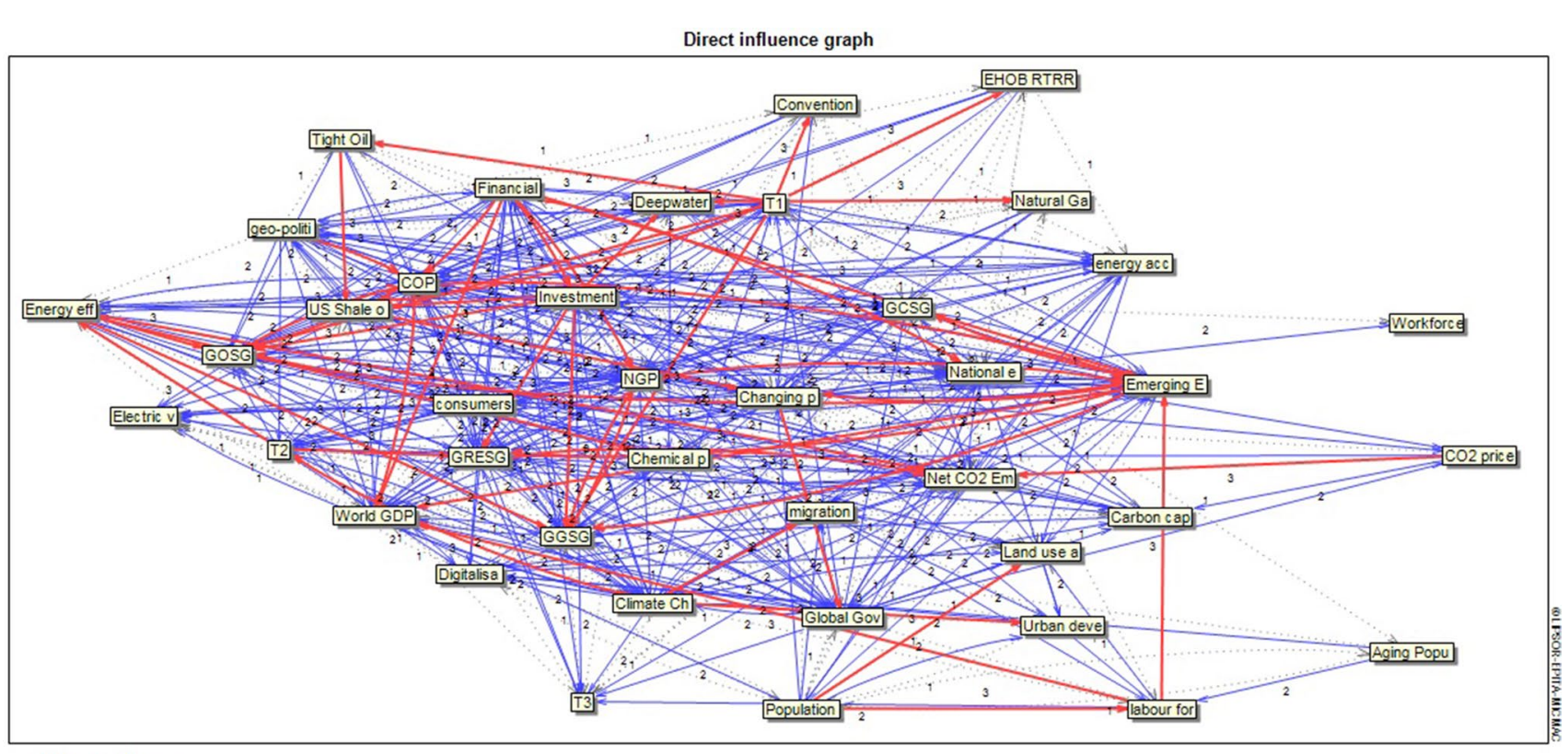

\footnotetext{
Weakest influences

- Weak influences

- Relatively strong influences

- Strongest influences
}

Fig. 16 Potential direct influence graph

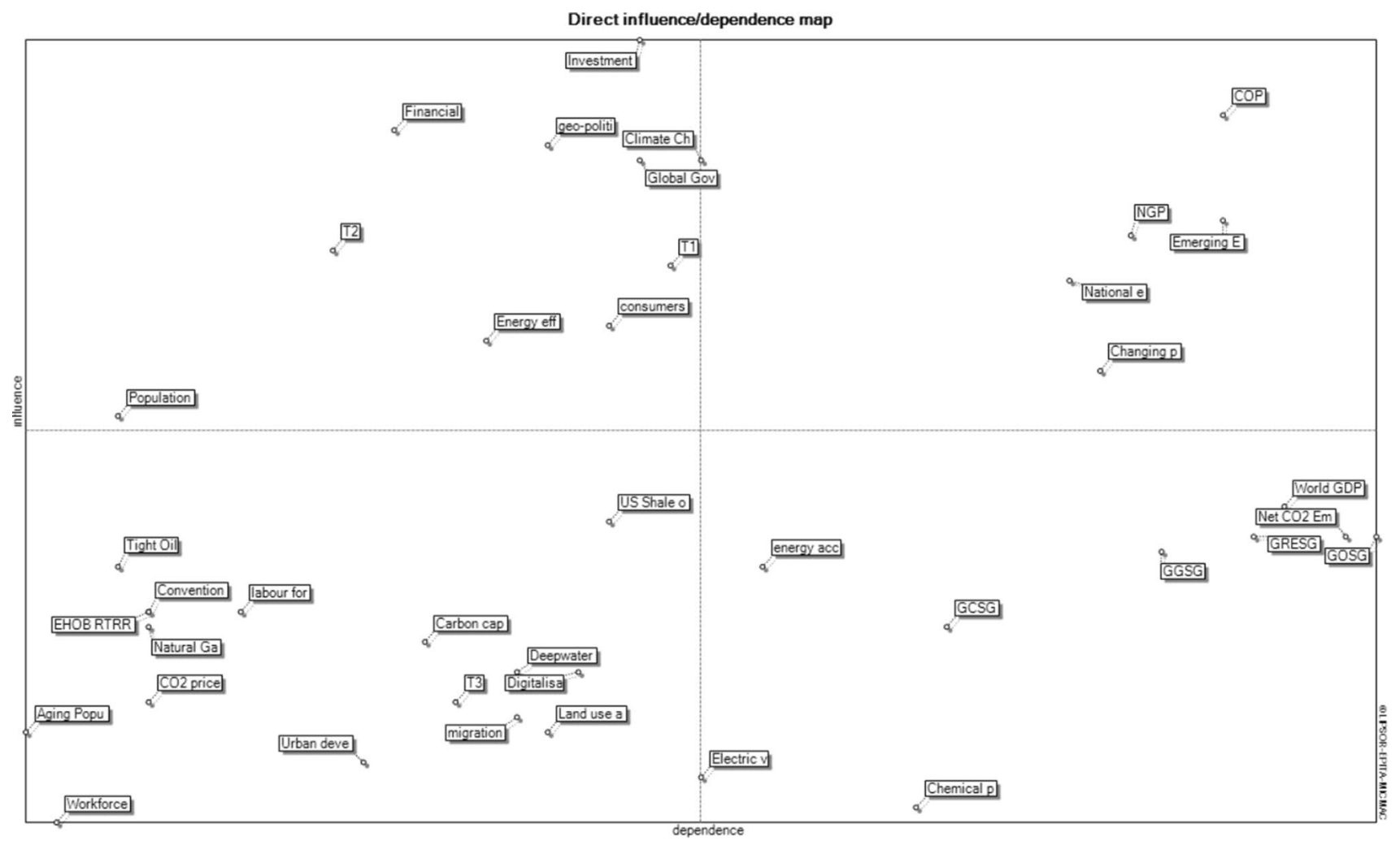

Fig. 17 Potential direct influence/dependence map 
Among the political variables reviewed in this research, the global governance, geopolitical relationships and tensions are identified as driving forces.

According to cross-impact analysis, the crude oil and natural gas price, emerging economies GDP growth, changing power blocs and national energy policies act as relay factors in Quadrant I. These key factors play a significant supporting role in the future of the world energy markets. Among the key factors of Quadrant I, crude oil price (COP) is the strongest relay factor due to highest influence and dependency, simultaneously.

Among autonomous factors within Quadrant III, the workforce productivity has no influence on global energy system's behavior, while US shale oil production is the most effective one. Based on the result of this study, world GDP growth is the most important result factor with low influence and high dependence in Quadrant IV. This implies that the world GDP growth does not play a leading role in the future of international energy markets and has a lower impact as compared with emerging economies' GDP growth located in Quadrant I.

\section{Results and discussion}

Since the 1970s, the uncertainties existing in global energy system have been of prime practical significance. Given the serious concerns such as security of energy supply, lack of investment in energy infrastructure, climate change, geopolitical tensions, pace of technological developments in renewables, inappropriate global governance and government intervention, the outlook of global energy markets in the long run is becoming much more sophisticated. Under these circumstances, future studies in the field of energy are of great importance.

In light of the foregoing discussion, this study seeks to overview and analyze future images of the global energy system presented by selected scenarios.

The global energy scenarios reviewed in this study are selected based on a crucial considerations such as international validity, covering all types of scenarios, diversity of authorship, including international petroleum corporations, global policy agencies, international NGOs and global policy networks.

This study analyzes energy scenarios' outputs and outlooks by 2040 such as gross domestic product, growth, technology developments, primary energy demand by sector, energy supply by fuel, energy intensity and carbon emissions.

Since the driving forces play significant roles in reshaping the world energy future, identifying the key drivers of global energy system is the most important and crucial part of a energy scenarios analysis. Hence, after extraction of 40 key factors of global energy system based on the academic literature of global energy systems and reviewed energy scenarios, in the final phase, this study presents the driving forces of world energy markets according to foresight semiquantitative method.

The nine scenarios reviewed in this study are: WEC's Hard Rock, Modern Jazz and Unfinished Symphony, Shell's Blueprints and Scramble, IEA Bridge, BP Energy Outlook, ExxonMobil's Outlook for Energy and Greenpeace's Energy Revolution.

These scenarios cover all three conventional types of scenarios. BP and ExxonMobil energy outlook are Predictive scenarios that predict what is going to happen in the future. WEC and Shell energy scenarios are Explorative scenarios that explore situations or developments that are regarded as possible to happen. The third types are Normative scenarios like Greenpeace and IEA Bridge that focus on achieving a specific goal in future.

These scenarios are different in terms of scenario framework. Shell is categorized in Storyline, ExxonMobil and BP in Outlook, IEA and Greenpeace in Outlook and Intervention and WEC in Exploratory Reference framework.

This section provides a quantitative and analytical overview of the scenarios and compares them.

One of the most important assumptions that plays an important role in shaping the global energy future, especially revolutionary scenarios, is the technology advancement.

One of the major differences between these scenarios is the state of technology development in different sectors of energy supply and demand (Table 3 ). The red, green and grey colors stand for undesirable, desirable and not mentioned. Each scenario contains a set of energy supply and demand technologies.

In WEC scenarios, a wide range of primary energy generation technologies such as renewable energy, nuclear power and hydro power have been considered. In these scenarios, technology development in energy efficiency, digitalization, decarbonization, electrical vehicles has been considered as the key assumptions.

The Gp-ER scenario, which is based on the revolutionary development of technology, also encompasses a variety of technologies except digitization. In the Shell and IEA bridge scenarios, all technologies except hydrogen production technologies and digitization have been considered. The important point is that among the scenarios that consider one type of technology, the rate of technological progress may vary.

For example, solar energy has been taken into account in all three WEC scenarios, but the technology development of solar energy in the Hard Rock scenario is a continuation of the current trend. In the Modern Jazz scenario, a gradual technology development scenario has been assumed, while the Unfinished Symphony scenario has considered a revolutionary and significant technology progress. 
Table 3 Technologies applied in selected global energy scenarios

\begin{tabular}{|c|c|c|c|c|c|c|c|c|c|}
\hline \multicolumn{2}{|c|}{ Section $\quad$ Scenario } & $\begin{array}{l}\text { WEC } \\
\text { hard } \\
\text { rock }\end{array}$ & $\begin{array}{l}\text { WEC } \\
\text { modern } \\
\text { Jazz }\end{array}$ & $\begin{array}{l}\text { WEC } \\
\text { unfinished } \\
\text { symphony }\end{array}$ & Shell & $\begin{array}{l}\text { BP EO- } \\
2017\end{array}$ & $\begin{array}{l}\text { IEA } \\
\text { bridge }\end{array}$ & Gp-ER & ExxonMobil \\
\hline \multirow{11}{*}{$\begin{array}{l}\text { Supply } \\
\text { side }\end{array}$} & Hydropower & $x$ & $\mathrm{X}$ & $\mathrm{X}$ & $\mathrm{X}$ & $\mathrm{X}$ & $\mathrm{X}$ & $\mathrm{X}$ & Non \\
\hline & Biomass & $\mathrm{X}$ & $\mathrm{x}$ & X & $\mathrm{X}$ & $\mathrm{X}$ & X & $x$ & $\mathrm{X}$ \\
\hline & Geothermal & $\mathrm{x}$ & $\mathrm{X}$ & $\mathrm{X}$ & $\mathrm{X}$ & $\mathrm{x}$ & $\mathrm{X}$ & $\mathrm{X}$ & $x$ \\
\hline & Solar & $\mathrm{x}$ & $\mathrm{X}$ & $\mathrm{x}$ & $\mathrm{X}$ & $\mathrm{X}$ & $\mathrm{X}$ & $\mathrm{X}$ & X \\
\hline & Solar PV & $\mathrm{X}$ & $\mathrm{x}$ & $\mathrm{X}$ & $x$ & $\mathrm{X}$ & $\mathrm{X}$ & $\mathrm{X}$ & $\mathrm{X}$ \\
\hline & Solar thermal & $\mathrm{X}$ & $\mathrm{X}$ & $\mathrm{X}$ & $\mathrm{X}$ & $\mathrm{X}$ & $\mathrm{X}$ & $\mathrm{X}$ & $\mathrm{X}$ \\
\hline & Wind & $\mathrm{x}$ & $\mathrm{X}$ & $\mathrm{X}$ & $\mathrm{X}$ & $\mathrm{X}$ & $\mathrm{X}$ & $\mathrm{X}$ & $\mathrm{X}$ \\
\hline & Ocean & $\mathrm{x}$ & $\mathrm{X}$ & $\mathrm{X}$ & $\mathrm{X}$ & Non & $\mathrm{X}$ & $\mathrm{X}$ & $\mathrm{X}$ \\
\hline & Biofuels & $\mathrm{X}$ & $\mathrm{X}$ & $\mathrm{X}$ & $\mathrm{X}$ & $\mathrm{X}$ & $\mathrm{X}$ & $\mathrm{X}$ & Non \\
\hline & Nuclear & $\mathrm{X}$ & $\mathrm{X}$ & $\mathrm{X}$ & $\mathrm{X}$ & $\mathrm{X}$ & $\mathrm{X}$ & $\mathrm{X}$ & $\mathrm{X}$ \\
\hline & Hydrogen & $\mathrm{X}$ & $\mathrm{X}$ & $\mathrm{X}$ & Non & Non & Non & $\mathrm{X}$ & $\mathrm{X}$ \\
\hline \multirow{4}{*}{$\begin{array}{l}\text { Demand } \\
\text { side }\end{array}$} & Energy effiency & $\mathrm{X}$ & $\mathrm{X}$ & $\mathrm{X}$ & $\mathrm{X}$ & $\mathrm{X}$ & $\mathrm{X}$ & $\mathrm{X}$ & $\mathrm{X}$ \\
\hline & Electrical vehicles & $\mathrm{X}$ & $\mathrm{X}$ & $\mathrm{x}$ & $\mathrm{x}$ & $\mathrm{x}$ & $\mathrm{x}$ & $\mathrm{x}$ & $\mathrm{X}$ \\
\hline & Digitalization & $\mathrm{X}$ & $\mathrm{x}$ & $\mathrm{X}$ & Non & $\mathrm{x}$ & Non & Non & Non \\
\hline & Decarbonization & $\mathrm{X}$ & $\mathrm{X}$ & $\mathrm{X}$ & $\mathrm{X}$ & $X$ & X & $\mathrm{X}$ & $\mathrm{X}$ \\
\hline
\end{tabular}

Based on a comparative analysis of global energy scenarios, the basic requirement for realizing revolutionary scenarios such as blueprints, modern jazz and Gp-ER scenario is pursuing collaborative approach, decarbonization policies and technology developments.

All of the energy scenarios predicted the economic prosperity and GDP increase through the projection period.

In Modern Jazz, Unfinished Symphony and Shell Blueprints scenarios, due to international collaborative actions, open-access technologies, and free-market economic systems, GDP will increase 147, 117, 110 percent in by 2030 referred to 2015, whereas in Shell Scramble and WEC Hard Rock scenarios, GDP increase about 73 and 57\%, respectively, over 2015-2030).

ExxonMobil EO-2017 and British Petroleum EO-2017 predict 105 and 94 percent GDP growth which shows the world's current collaborative status. Furthermore, strict decarbonizing scenarios such as IEA Bridge and Gp-ER forecast $89 \%$ and $94 \%$ of GDP growth means that turning to non-contaminating technologies does not significantly disrupt the economic prosperity. In these scenarios, an increasingly rapid shift is predicted in the electrical demand sector (world's electrification of BP).
In the decarbonization scenarios like Gp-ER, 147\% increase in electricity demand is predicted, also Modern Jazz's higher rate of increase (64\% compared to $49 \%$ average increase rate) shows that the electrification is greatly applied for this modern free market scenario and also IEA bridge scenario which applied innovation and technologies to control the demand in the term of increasing efficiency greatly electrifies the world (OPEC 2017).

The global trend over the energy intensity mentioned in Fig. 18 illustrates its decrease by 2015-2030. Scenarios with the free market and International collaborative approach are much more efficient in breaking the link between energy consumption and economic growth.

In Blueprints, WEC Unfinished Symphony, and WEC Modern Jazz, energy intensity decreased by $-28 \%$, $-48.5 \%$ and $-49.5 \%$, respectively, that shows the openaccess information and technology significantly affect energy efficiency development. Furthermore, decarbonizing scenarios including Gp-ER due to utilizing more advanced and efficient technologies cause $-51.7 \%$ decreases in the energy intensity. The global interest in using natural gas instead of coal leads to rapid natural gas supply and gas industry development. 


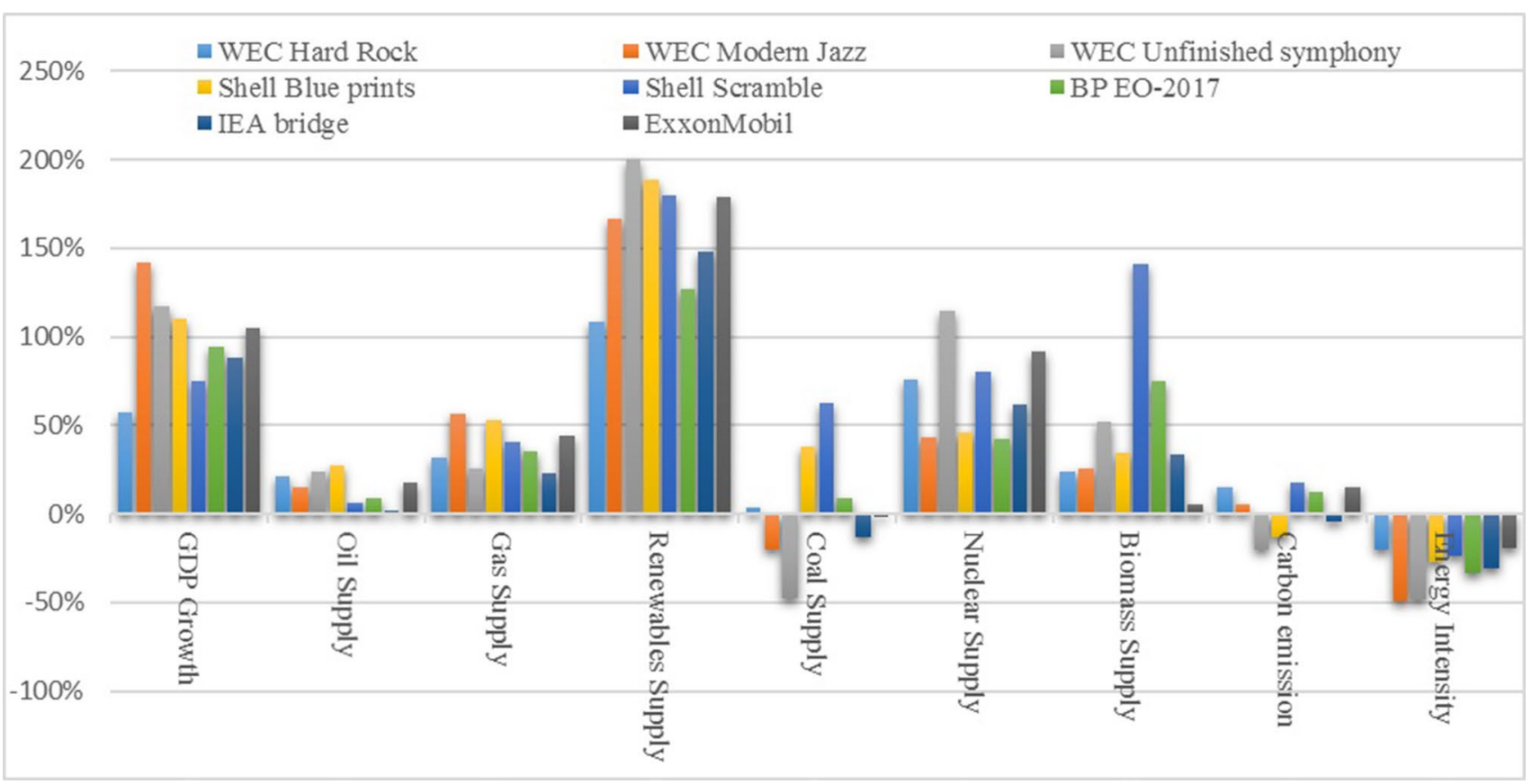

Fig. 18 Comparing major scenario's characteristics by 2015-2030 excluding Gp-ER

Table 4 Driving forces of global energy market

\begin{tabular}{lllll}
\hline Social & Technological & Economic & Environmental & Political \\
\hline Population growth & $\begin{array}{c}\text { Technology } \\
\text { developments } \\
\text { in renewables }\end{array}$ & Investment in infrastructure & Climate change & $\begin{array}{l}\text { Geo-political } \\
\text { relationships and } \\
\text { tensions }\end{array}$ \\
Consumer behavior & $\begin{array}{c}\text { Technology } \\
\text { developments } \\
\text { in petroleum } \\
\text { upstream }\end{array}$ & Financial shocks & & \\
& Enebal governance \\
& & & & \\
\hline
\end{tabular}

World gas supply increases 56\%, 53\% and 46\%, in Modern Jazz, Blueprints and Unfinished Symphony relatively caused by open access to fossil fuels and higher carbon efficiency in the gas supply consumers compared to the coal. The carbon emission decrease by $-20.3 \%$ and $-13.4 \%$ in Unfinished Symphony and Blueprints during 2015-2030 describes the successful environmental trend.

The carbon emission in Shell's Blueprints, WEC's unfinished symphony, IEA-Bridge, and Gp-ER is predicted: $-13.4 \%,-20.3 \%,-4 \%$ and $-62.4 \%$ decrease by 2015-2030. Reference scenario (BP) forecasts $12.5 \%$ increase in the emissions during this period which is more likely to the undesirable conditions of the scramble and the hard rock scenarios (local and national approach over the interests and denying collaborative environmental actions).

In this study, after reviewing the features and results of selected energy scenarios, key factors and driving forces of the global energy system are identified.
One of the fundamental requirements for analyzing the prospects of long-term energy markets and outlining future scenarios for the world energy system is the identification of key factors.

According to scenario building methods, key factors are generally classified into social, technological, economic, environmental and political dimensions. This research has identified forty key factors affecting the global energy future by reviewing the academic literature and various global energy scenarios.

Among the key factors extracted, some have the most impact on the others and receive the least impact. These key factors, called driving forces, play the most important role in reshaping the world's energy future. Another finding of this study, presented in Table 4, is the identification of global energy system's driving forces.

According to the findings of this study, the ten driving forces will have the most impact on the future of the world's 
energy. Based on cross impact analysis method, the driving forces in terms of importance and extent of impact are investment in infrastructure, financial shocks, geo-political relationships and tensions, climate change, global governance, technology developments in renewable, technology developments in petroleum upstream, energy efficiency, consumer behavior and population growth.

In terms of the STEEP framework, the identified driving forces of this research include three economic, two technological, two political, two social and one environmental factors.

Among the four environmental key factors extracted, only climate change was identified as the driving force because of its high impact on the other key factors.

Among political drivers, geo-political relationships and tensions and global governance were distinguished as the driving forces.

Consumer behavior and population growth are the two social driving force. In the technology group, technology developments in renewable and petroleum upstream were identified as global drivers due to significant influence on other key factors of the world energy system. Finally, among 17 economic key factors, investment in infrastructure, financial shocks and energy efficiency were identified as global driving force.

According to the results of the study, economic drivers play the most important role in shaping the future state of the global energy because of the number of drivers and their significant total impact. It is noteworthy that the identified driving forces are somehow considered as key factors in all the selected energy scenarios studied.

In addition to driving forces, there are other key factors called "relay factors" that play a significant supporting and complementary role in shaping the global energy transition out to 2040 and the key uncertainties surrounding. This study reveals that national energy policies, changing power blocs, crude oil and natural gas prices, and GDP growth in emerging economies are the five key factors that act as relay variables.

\section{Conclusion}

In this paper, selected energy reports are reviewed to show international mindsets about energy futures and share of energy resources in the global market.

Scenarios are stories about plausible long-term futures. Besides the knowledge they bring, scenarios make it possible to share understandings about futures. Scenarios show how different driving forces initiate events, shape trends, and create structures for possible futures.
In all of the scenarios reviewed in this paper, except GP-ER, the fossil fuels remain the first provider of the energy, but the share of renewable energy of world energy supply increases sharply.

Long-term overview of the world current situation shows that the world's current trend drives to economic and energy status similar to undesirable Shell's Scramble and WEC's Hard-Rock scenarios with the local view interests. World's most probable path to the future of economic growth and environmental developmentś depends on how the nations collaborate in these issues.

Although different reports suggested different paths to future, in many cases they have proposed similar trends. As the most important, almost all energy outlooks estimated an adjusted coal share, as it has a great contribution to greenhouse gasses emissions. In addition, RE resources will increase their share, especially in the term of electricity supply.

To address growing energy demands, oil and natural gas still will provide about two-third of total energy demand, however, due to upstream technology developments and being environment friendly natural gas grows with a steeper slope. As noted, environmental concerns are impressing energy policies, but nuclear power is still challenging. European countries are going to retire nuclear power plants referring to possible disastrous accidents, while India and China are planned to launch new plants.

In all scenarios, electricity demand growth is an inevitable future due to transport electrification, growing urban lifestyles and rising incomes.

All reviewed scenarios see a significant role of population growth and consumer behavior in future.

Based on the comparative analysis of global energy scenarios, pursuing collaborative approach, renewable technologies developments and accelerating digitalization are the essential elements in the transition towards a global low-orzero carbon emissions energy future.

All global energy scenarios direct attention to the need for coordinated action and policies on global climate change as the most important environmental driving force.

According to the findings of this study, the realization of a desirable future with global economic growth and low emissions is achieved by good global governance, a high level of investment in energy infrastructures and significant energy efficiency growth.

Reviewed scenarios describes that developments in the global financial system and geo-political relationships and tensions can constrain or accelerate successful global energy transition.

Though existence of a global shared vision is very valuable, national energy polices and outlooks should not be ignored. The international macro image, and corresponding policies, may contradict the national image, referring to 
countries challenges, capacities and potentials, especially in the case of energy supplier countries.

Acknowledgements The authors appreciate the generous feedbacks from the 40 member of expert panel of this research. We are grateful to Prof. Masoud Derakhshan, Mr. Ali Asghar Arshi, Mr. Gholamhassan Hasantash, Dr. Kazem Kashefi, Dr Mehdi Sadeghi Shahdani and Dr. Afshin Javan whose comments and suggestions have greatly benefited the paper. Finally, we would like to extend our gratitude to Prof. M. Abbaspour and anonymous referees for their insightful comments, which improved earlier version of manuscript. This study was developed and enhanced based on the Ph.D,'s thesis of the first author, at Allameh Tabataba'i University, Department of Energy, Agriculture and Environmental Economics in 2018 and has been evolved and improved since then.

Funding No financial funding was received for conducting this research.

\section{Compliance with ethical standards}

Conflict of interest All authors declare that they have no conflict of interest.

Ethical approval All procedures performed in studies involving human participants were in accordance with the ethical standards of the institutional and/or national research committee (include name of committee + reference number) and with the 1964 Helsinki Declaration and its later amendments or comparable ethical standards. This article does not contain any studies with human participants performed by any of the authors.

Open Access This article is licensed under a Creative Commons Attribution 4.0 International License, which permits use, sharing, adaptation, distribution and reproduction in any medium or format, as long as you give appropriate credit to the original author(s) and the source, provide a link to the Creative Commons licence, and indicate if changes were made. The images or other third party material in this article are included in the article's Creative Commons licence, unless indicated otherwise in a credit line to the material. If material is not included in the article's Creative Commons licence and your intended use is not permitted by statutory regulation or exceeds the permitted use, you will need to obtain permission directly from the copyright holder. To view a copy of this licence, visit http://creativecommons.org/licenses/by/4.0/.

\section{References}

Abbaszadeh P, Maleki A, Alipour M, Maman YK (2013) Iran's oil development scenarios by 2025. Energy Policy 56:612-622

Alhajji A, Andreasson S, Brogdon L, Hunter T, Khajehpour B, Mitrova T, Morales I, Murphy TB, Popp S, Slattery M (2018). Global impact of unconventional energy resources. Lexington Books, New York

Alipour M, Hafezi R, Amer M, Akhavan AN (2017) A new hybrid fuzzy cognitive map-based scenario planning approach for Iran's oil production pathways in the post-sanction period. Energy 135:851-864

Alipour M, Hafezi R, Ervural B, Kaviani MA, Kabak Ö (2018) Longterm policy evaluation: application of a new robust decision framework for Iran's energy exports security. Energy 157:914-931
Amer M, Daim TU, Jetter A (2013) A review of scenario planning. Futures 46:23-40

Ansari D, Holz F (2019) Anticipating global energy, climate and policy in 2055: constructing qualitative and quantitative narratives. Energy Res Soc Sci 58:101250

Arcade J, Godet M, Meunier F, Roubelat F (1999) Structural analysis with the MICMAC method and actor's strategy with MACTOR method. Futures Research Methodology, American Council for the United Nations University: The Millennium Project 2010

Ayres RU, van den Bergh JCJM, Lindenberger D, Warr B (2013) The underestimated contribution of energy to economic growth. Struct Change Econ Dyn 27:79-88

Bahrami M, Abbaszadeh P (2013) An overview of renewable energies in Iran. Renew Sustain Energy Rev 24:198-208

Benedict BA (2017) Benefits of scenario planning applied to energy development. Energy Proc 107:304-308

Bentham J (2014) The scenario approach to possible futures for oil and natural gas. Energy Policy 64:87-92

Bhattacharyya SC (2011) Energy economics: concepts, issues, markets and governance. Springer, Berlin

Bhattacharyya SC, Timilsina GR (2010) A review of energy system models. Int J f Energy Sect Manag 4(4):494-518

Bishop P (2007) The current state of scenario development: an overview of techniques. Foresight 9(1):5-25

Blazev AS (2016) Global energy market trends. CRC Press, Boca Raton

Börjeson L, Höjer M, Dreborg K-H, Ekvall T, Finnveden GJF (2006) Scenario types and techniques: towards a user's guide. Future 38(7):723-739

Boucher WI, Amara R (1977) The study of the future: an agenda for research. National Science Foundation, New York

BP (2017) BP energy outlook. British Petroleum

BP (2019) Statistical review of world energy. British Petroleum

Bradfield R, Wright G, Burt G, Cairns G, Van Der Heijden K (2005) The origins and evolution of scenario techniques in long range business planning. Futures 37(8):795-812

Cao K-K, Cebulla F, Vilchez JJG, Mousavi B, Prehofer SJE (2016) Raising awareness in model-based energy scenario studies-a transparency checklist. Energy Sustain Soc 6(1):28

Carrington G, Stephenson J (2018) The politics of energy scenarios: are International Energy Agency and other conservative projections hampering the renewable energy transition? Energy Res Soc Sci 46:103-113

Chaharsooghi S, Rezaei M, Alipour M (2015) Iran's energy scenarios on a 20-year vision. Int J Environ Sci Technol 12(11):3701-3718

Cherp A, Vinichenko V, Jewell J, Brutschin E, Sovacool B (2018) Integrating techno-economic, socio-technical and political perspectives on national energy transitions: a meta-theoretical framework. Energy Res Soc Sci 37:175-190

Cuhls K (2003) From forecasting to foresight processes-new participative foresight activities in Germany. J Forecast 22:93-111

Culka MJE (2018) Quantitative scenario design with Bayesian model averaging: constructing consistent scenarios for quantitative models exemplified for energy economics. Energy Sustain Soc 22(1):8

Dahl CA (2015) International energy markets: understanding pricing, policies, and profits, 2nd edn. PennWell Books, Oklahoma

EIA (2016) International energy outlook 2016, US Energy Information Administration

EREC (2012) Energy revolution. Green Peasce 
Ernst A, Biß KH, Shamon H, Schumann D, Heinrichs HU (2018) Benefits and challenges of participatory methods in qualitative energy scenario development. Technol Forecast Soc Chang 127:245-257

ExxonMobil (2017) Outlook for energy: a view to 2040. ExxonMobil

Florini A, Sovacool B (2009) Who governs energy? The challenges facing global energy governance. Energy Policy 37:5239-5248

Fontela E, Hingel A (1993) Scenarios on economic and social cohesion in Europe. Futures 25(2):139-154

Gielen D, Boshell F, Saygin D, Bazilian MD, Wagner N, Gorini R (2019) The role of renewable energy in the global energy transformation. Energy Strat Rev 24:38-50

Gilbert AQ, Sovacool BK (2016) Looking the wrong way: bias, renewable electricity, and energy modelling in the United States. Energy 94:533-541

Glenn JC, Gordon TJ (2009) Futures research methodology-version 3-0. Editorial Desconocida

Godet M (2000) The art of scenarios and strategic planning: tools and pitfalls. Technol Forecast Soc Chang 65(1):3-22

Godet M (2006) Creating futures: scenario planning as a strategic management tool. Economica, London

Goldemberg J (2000) World energy assessment: energy and the challenge of sustainability. United Nations Development Programme New York

Goldthau A (2016) The handbook of global energy policy. Wiley, Berlin

Gordon TJ (1994) Cross-impact method. American Council for the United Nations University

Gordon TJ, Glenn J (2018) Interactive scenarios. In: Moutinho L, Sokele M (eds) Innovative research methodologies in management: volume II: futures, biometrics and neuroscience research, vol II. Springer, Cham, pp 31-61

Greenpeace (2015) Energy revolution 2015. Greenpeace

Grubler A, Jefferson M, McDonald A, Messner S, Nakicenovic N, Rogner H-H, Schrattenholzer L (1995) Global energy perspectives to 2050 and beyond, Joint IIASA and World Energy Council Report, World Energy Council, London, UK

Grübler A, Jefferson M, Nakićenović N (1996) Global energy perspectives: a summary of the joint study by the international institute for applied systems analysis and world energy council. Technol Forecast Soc Chang 51(3):237-264

Hafezi R (2019) How artificial intelligence can improve understanding in challenging chaotic environments. World Fut Rev 1946756719880539

Hafezi R, Akhavan A, Pakseresht S (2017) Projecting plausible futures for Iranian oil and gas industries: analyzing of historical strategies. J Nat Gas Sci Eng 39:15-27

Hafezi R, Malekifar S, Akhavan A (2018) Analyzing Iran's science and technology foresight programs: recommendations for further practices. Foresight 20(3):312-331

Hafezi R, Akhavan A, Pakseresht S, Wood DA (2019) A layered uncertainties scenario synthesizing (LUSS) model applied to evaluate multiple potential long-run outcomes for Iran's natural gas exports. Energy 169:646-659

Hamrin J, Hummel H, Canapa R (2007) Review of renewable energy in global scenarios. Center for Resource Solutions, Report prepared for IEA Implementing Agreement on Renewable Energy Technology Deployment. http://www.iea-retd.org/files/REVIEW\%20 OF\%20RENEWABLE\%20ENERGY 20

Huang Y (2014) Drivers of rising global energy demand: the importance of spatial lag and error dependence. Energy 76:254-263
IEA (2015) World energy outlook special report. International Energy Agency

Jefferson M (2000) Long-term energy scenarios: the approach of the world energy council. Int J Glob Energy Issues 13:277-284

Jefferson M (2012) Shell scenarios: what really happened in the 1970s and what may be learned for current world prospects. Technol Forecast Soc Chang 79(1):186-197

Johansson B (2013) Security aspects of future renewable energy systems-a short overview. Energy 61:598-605

Jungk R, Müllert NR (1996) Future workshops: how to create desirable futures. Institute for Social Inventions, London

Junne T, Xiao M, Xu L, Wang Z, Jochem P, Pregger T (2019) How to assess the quality and transparency of energy scenarios: results of a case study. Energy Strat Rev 26:100380

Kopetz H, Haara K, Kummamuru B (2015) WBA global bioenergy statistics 2015. World Bioenergy Association. http://worldbioen ergy.org/content/wbalaunches-global-bioenergy-statistics-2015. Accessed 18

Masini EB (2001) New challenges for futures studies. Futures 33(7):637-647

Mietzner D, Reger G (2005) Advantages and disadvantages of scenario approaches for strategic foresight. Int J Technol Intell Plan $1(2): 220-239$

Miles I (2008) From futures to foresight. In: Georghiou L, Harper JC, Keenan M, Miles I, Popper R (eds) The handbook of technologyforesight: concepts and practice. Edward Elgar Publishing, Cheltenham, UK, Northampton, MA, USA, pp 24-43

Mohn K (2016) Undressing the emperor: a critical review of IEA's WEO. University of Stavanger

Nakicenovic N, Grübler A, McDonald A, Analysis IIFAS, Council WE (1998) Global energy perspectives. Cambridge University Press, Cambridge

Pearson P (2016) Energy policies in an uncertain world. Springer, Berlin

Pillkahn U (2008) Using trends and scenarios as tools for strategy development: shaping the future of your enterprise. Wiley, Berlin

Popper R (2008a) Foresight methodology. In: In: Georghiou L, Harper JC, Keenan M, Miles I, Popper R (eds) The handbook of technologyforesight: concepts and practice. Edward Elgar Publishing, Cheltenham, UK, Northampton, MA, USA, pp 44-88

Popper R (2008b) How are foresight methods selected? Foresight 10(6):62-89

Popper R, Medina J (2008) 12. Foresight in Latin America. In: In: Georghiou L, Harper JC, Keenan M, Miles I, Popper R (eds) The handbook of technologyforesight: concepts and practice. Edward Elgar Publishing, Cheltenham, UK, Northampton, MA, USA, pp 256-286

Schoemaker PJ (1991) When and how to use scenario planning: a heuristic approach with illustration. J Forecast 10(6):549-564

Schwartz P (2012) The art of the long view: planning for the future in an uncertain world. Crown Business

Shell (2011) Shell energy scenarios to 2050. Shell International BV

Stern DI (2010) The role of energy in economic growth. USAEE-IAEE working paper (10-055)

UN (2019) World population prospects 2019. Department of Economic and Social Affairs, United Nations, New York

Voros J (2003) A generic foresight process framework. Foresight $5(3): 10-21$

Wack P (1985) Ж scenarios: uncharted waters ahead. Harvard Business Review September-October 
Wang Q, Li R (2016) Drivers for energy consumption: a comparative analysis of China and India. Renew Sustain Energy Rev 62:954-962

WEC (2016) World energy scenarios. World Energy Council

Yergin D (2011) The prize: the epic quest for oil, money and power. Simon and Schuster
Zahid S, Bhatti AA, Ahmad Khan H, Ahmad T (2007) Development of unconventional gas resources: stimulation perspective. In: Production and operations symposium. Society of Petroleum Engineers

Zalik A (2010) Oil 'futures': shell's scenarios and the social constitution of the global oil market. Geoforum 41(4):553-564 